\title{
Tüketici Sinizmi Kavramı ve Ağızdan Ağıza Pazarlama Eylemlerinin Sinik Tüketici Davranışlarına Etkisi Konusunda Bir Uygulama
}

\author{
DOI: $10.26466 /$ opus.581400 \\ *

\section{Bora Göktaș} \\ * Dr. Öğr. Üyesi, Bayburt Üniversitesi Uygulamalı Bilimler Fakültesi Yönetim Bilişim Sistemleri \\ Bölümü, Bayburt/Türkiye \\ E-Posta: boragoktas@bayburt.edu.tr \\ ORCID: $\underline{0000-0003-2159-0241}$
}

\section{Öz}

Markayı satın alma işlemini gerçekleştiren bir tüketici markanın sunduğu vaatlerle kullanım sonucunda gerçekleşen arasında bir tutarsızlı gördüğ̈̈nde bir memnuniyetsizlik duyacaktır. Dahası müşteri markalardan şüphe edebilecek ve sonraki satın alma davranışlarında bir kayg̨ içerisine düşebilir ve bu da belirsizliği attırabilmektedir. Sonuçta müşteri satın alma konusunda kuşkulara, kaygıya düşecektir ve aldatılma korkusu, güvensizlik gibi düşüncelere sahip olabilecek, markaların hilekar oldukları hissiyatına kapılabilecektir. Tüketicilerin böyle düşüncelere sahip olmasına pazarlama kavramı içerisinde "tüketici sinizmi" denmektedir. Ağızdan ağıza pazarlama ise; bir tüketicinin başka tüketicilerle markalar hakkında konuşması, onlara markanın olumlu ya da olumsuz yanlarını anlatarak etkilemişidir. Eldeki çalı̧̧ma ile de ağızdan ağıza pazarlamanın tüketicileri sinik davranışlara itip itmediği görülmeye çalışılmıştır. Bunun için öncelikle "tüketici sinizmi" ölçeği kullanılmış ve katılımcıların ne derece sinik oldukları anlaşılmaya çalışılmıştır. Sonrasında ise "ağgzdan ağıza pazarlama" ölçeği hazırlanmış ve ă̆ızdan ağıza pazarlamanın tüketici sinizmine etkisi belirlenmeye çalışılmıştır. Bu sinamayı yapabilmek amacıyla bir anket formu hazırlanmıs ve "kolayda örnekleme yöntemi" ile 476 katılımcıya gerçekleştirilmiştir. Bulgularda katıllmcıların az da olsa sinik tutumlara sahip olduklar ve yine azda olsa ă̆ızdan ă̆ıza pazarlamanın tüketici sinizmi üzerinde etkisi olduğu görülmüştür. Çalışmada dikkat çeken noktalar ise; erkekler daha sinik tutuma sahiptir, fakat kadınlar ağızdan ă̆gza pazarlamadan daha fazla etkilenerek sinik tutumlar sergilemektedir. "Tüketici sinizmi" ölçeğinde ve ă̆ızdan ağıza pazarlama ölçeğindeki "kaynağın uzmanlığı" ve "tavsiyenin aldatılmayı azaltması" faktörlerinde katılımclar yaş artııkça daha fazla; "tavsiyeye güven" faktöründeyse yaş azaldıkça daha sinik davranışlar göstermektedir. Ayrıca eğitim seviyesi arttıkça tüketicilerin hem sinik tutum dereceleri hem de de ă̆ızdan ă̆ıza pazarlama eylemleri ile sinik davranış seviyeleri artmaktadir.

Anahtar Kelimeler: Tüketici sinizmi, ağızdan ağıza pazarlama, tüketici davranışlar 


\title{
The Concept of Consumer Cynicism and A Survey on The Effect of Word of Mouth Marketing Actions on Cynical Consumer Behavior
}

\begin{abstract}
A consumer who purchases the mark will feel dissatisfied when he sees an inconsistency between the promises made by the brand and what happens as a result of use. Furthermore, the customer may doubt the brands and may be worried about their subsequent purchasing behavior, which may increase uncertainty. As a result, the customer will have doubts or concerns about the purchase and fear of deceiving, insecurity, will be felt by brands as deceitful. It is called "consumer cynicism" in the concept of marketing that consumers have such ideas. Word of mouth marketing is the fact that a consumer talks about brands with other consumers has influenced them by describing the positive or negative aspects of the brand. In this study, it has been tried to be seen whether word of mouth marketing pushes consumers to cynical behaviors. For this, firstly, "consumer cynicism" scale was used and it was tried to understand the degree of cynicism of the participants. Afterwards, "word of mouth marketing" scale was prepared and the effect of word of mouth marketing on consumer cynicism was tried to be determined. In order to perform this test, a questionnaire form was prepared and it was performed to 476 participants with convenience sampling method. It was observed that the participants had a slight cynic attitude and the word of mouth marketing had an effect on consumer cynicism. Points of attention in the study are as follows; men have more cynic attitudes, but women are more affected by word of mouth marketing and exhibit cynical attitudes. On the scale of consumer cynicism, participants show more cynic behaviors as age increases. The same can be seen in "the expertise of the resource" and "advice to reduce cheating" factors that belongs to the word of mouth marketing scale. In "trust to advice" factor, participants shows more sinic behavior as age decreases. In addition, as the level of education increases, cynical attitudes of consumers increase. Likewise, as the level of education increases, the level of cynic behavior increases with the word of mouth marketing actions of the consumers.
\end{abstract}

Keywords: Consumer cynicism, word of mouth marketing, consumer behavior 


\section{Giriş}

Markalar tüketicilerin kendilerini tercih etmesi için çeşitli pazarlama iletişimi çalışmaları yapmaktadır. Yaptıkları bu pazarlama iletişimi faaliyetlerinde tüketicilerin satın alma motivasyonlarını arttırabilmek için çeşitli vaatlerde bulunmaktadır ve bu vaatleri değerlendirip ikna olan tüketici markayı satın alma işlemini yerine getirmektedir. Markayı kullanan tüketici bu deneyimden memnun kaldığında marka ile olan temasa devam edecektir; fakat tersi olduğunda ise iletişimi kesecektir. İlişkisel pazarlamanın genel çerçevesi de marka ile müşteri arasındaki ilişkiyi bu şekilde açıklamaktadır (ilişkiyi belirle, tesis et, sürdür ve gerektiğinde ilişkiyi kes). Müşteri ile marka arasında ilişki tesis edilecek, bu ilişki devam edecek, başka vaatlerle ilişki güçlendirilecektir. Ancak bu ilişkinin bu şekilde sürüp gitmesi için karşılıklı menfaatler söz konusudur. Markanın menfaati kar iken; müşterinin menfaati memnuniyettir.

İlişkisel pazarlamanın doğası gereği marka ile müşteri arasındaki ilişki uzun vadeli bir ilişki olmak zorundadır. İlişkisel pazarlama döneminde artık markanın müşterisi ile kurduğu tek gecelik ilişkiler değil kalıcı ilişkiler söz konusudur. Ancak bu ilişkinin kalıcı olması için gerekli müşteri memnuniyetin oluşması amacıyla markanın söyledikleri ile müşterinin karşılaştıkları örtüşmelidir. Eğer böyle bir örtüşme olmazsa müşteri marka ile olan ilişkisini bir menfaat (memnuniyet) elde edemediği için kesecektir. İlişkiyi kesen müşterinin davranışları da ister istemez sinik bir hal alabilecektir. Tüketicinin davranışları sinik bir hal aldığında; hayal kırıklığına uğramış bir kişi olarak markalara karşı olumsuz düşüncelere sahip olmaya başlayacaktır. Müşteri markalardan şüphe edebilmekte, kendisini kandırmaya çalışan markalar olduğunu ve güvenmemesi gerektiği hissine kapılabilmektedir. Böylece ortaya marka düşmanı bir tüketici kesimi doğabilmektedir. Bu tarz tüketicilere sinik tüketici denilmekte ve böyle bir akıma da tüketici sinizmi denmektedir.

Müşterinin markalara karşı olumsuz düşüncesinin şiddeti farklı farklı seviyelerde olabilmektedir ve bu seviyeye göre de sinik olma derecesi şiddetli ya da hafif olabilecektir. Markaların da karşısında tüketici sinizmi kavramı ile başa çıkmak gibi bir sorun bulunmaktadır. Markalar sinik tüketici hareketlerini yok etmeye ya da yok edemiyorsa azaltmaya yönelik eylemler ortaya koymak durumundadır. SWOT analizinde temel dört 
stratejisi; çevir (zayıf yönleri güçlü yönlere, tehditleri fırsatlara çevir), yakala (pazardaki fırsatları güçlü yönleri kullanarak yakala), yok et ( pazardaki tehditleri yok et) ve minimize et (eğer tehditleri yok edemiyorsan vereceği hasarı en aza indir) stratejilerdir. Bu durumda tüketici sinizmi kavramı markalar için SWOT analizinde uygulanması (yok et ve minimize et stratejileri ile), önlem alması gereken bir sorun olarak görünmektedir.

Sinik tüketici, önceden de bahsedildiği gibi, markanın verdiği vaatler ile yaşadıkları uyuşmadığında artık markanın olumsuzluklarını düşünecektir. Peki, sinik bir tüketicinin bu olumsuz düşüncesini diğer tüketicilerle paylaşma olanağı yok mudur? Bu noktada karşımıza "ağızdan ağıza pazarlama" kavramı çıkmaktadır. Ağızdan ağıza pazarlama en basit tanımıyla tüketicilerin markalar hakkında başka tüketicilerle konuşmasıdır. Bir markanın kullanımından memnun kalan tüketiciler bunu diğer tüketicilere gönüllü olarak aktarmakta ve bir nevi ücretsiz olarak markanın pazarlamasını yapmaktadır. Ancak tersi olduğunda da bu kez olumsuz bir ağızdan ağıza pazarlama durumu söz konusu olacaktır.

Olumsuz ağızdan ağıza pazarlamaya yönelik bankacılık sektöründe yapılan bir araştırmada, memnun olmamış bir müşterinin, bankanın herhangi bir yanlışını 11 kişiye anlattığ 1 ve bu 11 kişinin de ortalama 5 kişiyle bu olayı paylaştığı belirlenmiştir (Yavuzyılmaz, 2008, s.69-72). Bankacılık sektöründe yapılmış bir araştırmayı destekleyecek şekilde bir markadan memnun kalan tüketicinin bu memnuniyeti 2-3 kişiyle paylaştı̆̆ı; fakat buna karşın memnuniyetsizliğini 7-8 kişiyle paylaştığına dair bulgular vardır. Bundan dolayıdır ki markalar her 10 kullanıcısından 8'ini mutlu etmeli ki markayla ilgili iyi bir konumlandırma, imaj ortaya çıksın (Göktaş, 2017, s.258). Tüketiciler, bir markayla ilgili yaşadığı olumsuzlukları diğer tüketicilerle büyük bir zevk duyarak paylaşmaktadırlar. Olumsuz ağızdan ağıza pazarlama konusunda yapılmış olan birçok araştırma bunun böyle olduğunu ortaya koymaktadır. Tüketiciler bir marka ile ilgili olumsuz deneyimleri, olumlu deneyimlerden daha fazla bir ortamda ve kişiyle konuşmakta ve markayı kötü yönde eleştirmektedir. Bizler nasıl rahatsız olduğumuz herhangi bir durumu diğer insanlara anlatarak rahatlıyorsak, olumsuz ağızdan ağıza pazarlama ile memnun olmadığımız markalar hakkında diğer tüketicilerle konuşup hem kendimizi rahatlatıyoruz hem de onları bilinçlendirmiş, markaya karşı uyarmış oluyoruz. 
Ülkemizde tüketici sinizmi hakkında pek az çalışma vardır. Alanyazın incelendiğinde batı toplumlarında tüketici sinizmi üzerine yapılmış pek çok araştırma mevcutken (Helm, 2004; Jahdi, 2006 ve 2009; Mikkonen vd., 2011; Dolen vd., 2012; Alhouti, 2013; Chowdhury ve Fernando; Bertilsson, 2015; Amezcua ve Quintanilla, 2016; Berdysheva ve Romanova, 2017; Balaji vd., 2018) ülkemizde durum böyle değildir. Ulusal tez merkezi tarandığında tüketici sinizmi konusunda hiçbir teze rastlanmadığı, çalışmaların daha çok örgütsel sinizm üzerine olduğu görülmektedir. Bundan dolayı işletme disiplininde sinizm üzerine çalışmalar daha çok yönetim ve organizasyon konusunda gerçekleştirilmiş tezlerdir ve pazarlama üzerine yapılmış tezler yoktur. Tüketici sinizmi üzerine yapılmış makale çalışmaları da sayısı çok az olmakla birlikte (Güven, 2016; Atılgan vd., 2017; Akgüç Çetinkaya ve Ceng, 2018), bunların içerisinde derleme çalışmalar da mevcut olup, araştırma makalesi olarak yapılmış çalışma sayısı kısıtlıdır. Bundan dolayı da eldeki çalışma ile tüketicilerinin ne derece sinik davranışlar sergilediği ve bu davranışların ağızdan ağıza pazarlama ile ilişkisi ortaya konarak alanyazına bir katkı sunmak amaçlanmıştır.

Olumsuz ağızdan ağıza pazarlama yukarıda bahsedildiği gibi markalar için tehlikeli ve başa çıkması gereken bir durumken, sinik tüketicinin de hayal kırıklığına uğradığı, markadan şüphe ettiği, aldatıldığı, ihanet edildiği hissiyatına sahip olduğu bir durumda olumsuz ağızdan ağıza pazarlamadan etkilenme durumunun da yüksek olması beklenmektedir. Buna karşın olumlu bir ağızdan ağıza pazarlamaya karşı ihtiyatlı yaklaşması, şüphe etmesi, zor ikna olması gibi durumlar da söz konusu olabilir. Eldeki çalışma ile tüketici sinizmi ile ağızdan ağıza pazarlama arasında bu yollu bir ilişki var mı ve ilişkinin boyutu tespit edilmeye çalışılacaktır. Bunun içinde öncelikle katılımcılar sinik bir tutuma sahip midir belirlenmeye çalışılmıştır ve eğer sinik bir tutuma sahipse ağızdan ağıza pazarlama eylemlerinden ne derece etkilenmektedir tespit edilmeye çalışılmıştır. Çalışmada öncelikle tüketici sinizmi ve ağızdan ağıza pazarlama kavramlarından ve bu kavramlar ile ilgili yapılmış olan çalışma sonuçlarından söz edilmekte, ardından da tüketici sinizmi ile ağızdan ağıza pazarlama arasındaki bahis geçen ilişkiyi belirlemeye yönelik bir uygulama sunulmaktadır. 


\section{Alanyazın Taraması}

\section{Tüketici Sinizmi}

Eski tanımlardan birinde sinizm; öğrenilmiş bir tutum olarak tanımlanmaktadır. "Insanlar beklentileri karşılanmadığında hayal kırıklığına uğradıklarını düşünür ve bu hayal kırıklığı düşüncesi, kendisinin küçümsendiği, aldatıl-

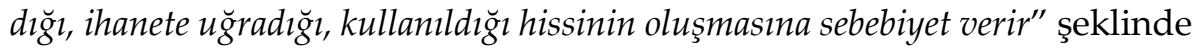
açıklanmıştır (Kanter ve Mirvis, 1989, s.3). Bu noktada sinizm basit bir anlatımla; diğerlerinden hoşlanmama ve diğerlerine güvenmeme, otorite ve kurumlara karşı olumsuz ve güvensiz tutumlar, engellenme, umutsuzluk ve hayal kırıklığı, kişi, grup, ideoloji, toplumsal gelenek veya kurumlara karşı negatif duygular ve güvensizlik, insanın niyet ve faaliyetlerinin iyilik ve samimiyetine inanmama eğilimi göstermesidir ( Arslan, 2012, s.13). Boş vaatler ya da doğru olmayan konumlandırmalar sinizmin kavramsallaştırılmasında kritik bir unsurdur. Tüketicilere gerçekçi olmayan beklentilerin yaratılması sinizmi ortaya çıkartmaktadır. Tüketicilere sunulan vaat ve marka için oluşturulan imaj ile gerçeklik arasındaki kopukluk sinizmin tüm tartışmalarını karakterize etmektedir (Helm, 2004, s.345). Tüketici sinizmi, tüketicileri koruma amaçlı, onların saf olmadıklarını gösterme çabalarıdır (Naletelich ve Ketron, 2017, s.11).

Sinik tüketiciler şüphe, düşmanlık ve karamsarlıkla karakterize edilir. Bu karaktere sahip tüketiciler markalara karşı güvensizlik hissedebilirler ve markaların yeteneklerinden şüphe edebilmektedirler. Bundan dolayı da markaların çabaları sinik tüketiciler tarafından olumsuz bir şekilde değerlendirmelerine yol açabilir. Bir nevi tüketicilerin sinik davranışları değerlendirme sürecinin adaletli bir şekilde değerlendirilmesi ve müşteri memnuniyeti konularına etki edebilir. Sinik tüketicilerin potansiyel olarak meydana çıkartabileceği ciddi sonuçları nedeniyle markalar sinizmin etkilerini yenmek için uygun müdahale stratejilerinin geliştirilebilmeli ve sinik tüketicilerin nasıl etkilendiğini daha iyi anlayabilmelidirler. Çünkü çalışma sonuçları göstermiştir ki, sinik davranışları yüksek olan müşteriler markayı daha adaletsiz değerlendirmekte ve daha fazla memnuniyetsizlik dile getirmektedirler. Buna karşın tüketicilerin sinik davranışları azaldıkça memnuniyet derecesi de artmaktadır. Hizmet sektörü üzerine 
yapılan bu çalışmada, tüketicilerin hizmet üretimine katılımı ile sinik davranışların hafifletilebileceği görülmüştür (Balaji vd., 2018, s.109-110). Bir başka anlatımla tüketiciler sinik davranış özellikleri gösterebilirler; ancak araştırmanın sonuçları da bunu göstermektedir ki bu davranışlar hafifletilebilecek ya da baskılanabilecek davranışlardır. Sinik tüketiciler aldatıldıkları algısına sahiptirler ve buda tüketicinin üründen şüphe etmesine ve dolaylı olarak tüketici tepkisini etkileyebilmektedir. Eğer tüketici satın alacağı marka ile ilgili önceden aldatıcı bir marka olduğuna dair bilgiye erişirse, daha fazla sinik davranış göstermektedir. Buna karşın markalar dürüstlük konusunda davranış sergilediklerinde ise tüketicilerin aldatıldıkları düşünceleri önlenebilmektedir (Ketron, 2016, s.33-34).

Sinik davranışların sıklığı ve ciddiyet derecesindeki artış, tüketicilerin hedefleri veya değerleri ile marka eylemleri arasındaki sürekli uyumsuzluktan kaynaklanmaktadır. Değer uyuşmazlığının sinik davranışların ciddiyeti üzerinde daha büyük bir etkisi vardır. Bu uyuşmazlıklar devam ettiğinde tüketicilerin giderek daha sık ve daha güçlü sinik davranışlarla tekrarlanan uyumsuzluğa yanıt verdiği görülmektedir. Yöneticiler, tüketicilerin belirli bir duruma nasıl tepki vereceğini tahmin etmeli ve bu tepkileri azaltmak için eylemler yapmalıdır. Çünkü sinik davranışlar yöneticiler tarafından tahmin edilenden daha hızlı bir şekilde ortadan kaldırılabilir (eğer uyumluluk oluşturacak çalışmalar yapılırsa). İşletmelerin mal ve hizmetleri ile tüketicinin değer uyumunun oluşmaması (üründen beklenen performansın görülmemesi) sinik davranışın çok önemli bir belirleyicisidir. Bu nedenle, markaların performans hedeflerine ulaşmak için kullandıkları yolların, tüketicilerin davranışsal tepkilerinde baskın bir faktör olabilme olasılığı bulunmaktadır (Chylinski ve Chu, 2008, s.816).

Defansif sinizm ve daha hafif şekli olan şüphecilik, pazarlama uyaranlarına karşı savunma amaçlı zihinsel araçlar olarak düşünülebilir. Bu tüketici grubu pazarlamacıların manipülasyon (hileli yönlendirme) girişimlerine direnmektedirler. Aldatılma korkusu, şüphe ve güvensizlik; telefonla satış, doğrudan satış veya genel olarak reklamcılık gibi satış tekniklerine yönelik olağan bilişsel tepkilerin bir parçasıdır. Tüketiciler pazarlama çalışmalarını ikna etmek için bir yöntem olarak görmekte ve buna karşı tüketiciler uyanık olmakta, ikna çabalarını hızlıca tespit edip direnç göstermektedirler. Ofansif sinizmde ise; tüketiciler sömürülmeye karş1 çıkmakta, işletmeleri söylemlerle kınamaktadır. Burada tüketici açıkça 
muhalefet etmekte, aktivist olarak tanımlanacak sosyal hareketler gerçekleştirmektedir( Odou ve De Pechpeyrou, 2011, s.801-802).

Tüketici sinizmi satın alma niyetlerini azaltmaktadır. Ayrıca kurumsal sosyal sorumluluk uygulamalarına ilişkin gönüllülük ya da mali yardım gibi destekler konusunda motivasyonları da düşürmektedir (Ogunfowora vd., 2015, s.1310). Markalar, çoğu zaman Kurumsal Sosyal Sorumluluk aracını kullanarak iyi görünmeye çalışmaktadır; fakat bazı uygulamalar hala tüketici tepkilerine yol açan sinizm ile karşılaşmaktadır (Samuel vd., 2018, s.53). Sinik tüketiciler; tüketicileri (sadece aktivistleri değil aynı zamanda sıradan tüketicileri de) bir piyasa sistemi oyuncuları olarak görürler ve sosyal olarak bilinçli seçimler yapma sorumluluğuna sahip olduklarına inanırlar (Helm vd. 2015, s.515). Markalar tüketici sinizminden kurtulabilmek için ticari kaynaklarını çevrimiçi iletişim ortamlara aktarmakta ve burada oluşacak reklam ile etkisini hafifletmeye çalışmaktadırlar (Ashley ve Leonard, 2009, s.212).

Tüketici sinizminin şüphe etkisi yeşil pazarlama uygulamalarında da görülmektedir (Jahdi, 2006, s.2). Tüketicilerin sinizmi derecesi, tüketicilerin pazarlama çabalarına tepkilerini açıklayabilir. Sinizm, başkalarının güdülerinden ve iyi şeylerinden şüphe olarak tanımlanan kişisel bir özellik ile ilişkili derin bir inançtır. Tüketiciler, bir işletmenin amaca yönelik pazarlama (cause related marketing) faaliyetleri konusunda da sinik bir davranış göstererek şüpheci yaklaşabilmektedir (Alhouti, 2013, s.41) ve bu şüpheci yaklaşım sektörlere balta vurabilmektedir. Misal olarak sindirim sağlığından temiz cilde kadar her şeyi vaat eden fonksiyonel gidalara yönelik sağlıksız olduğu iddiaları üzerine artan tüketici sinizmi sektörün büyümesinin önünde bir engel olarak durmaktadır. Araştırmalar tüketicilerin yaşadıkları hayal kırıklıklarının sektörlerinin büyümesini yavaşlattığını iddia etmektedir (Bokaie, 2008, s.1).

Sinizm kültürü tüketicilerin ürün ve fiyatları konusunda şüphe etmesine, çeşitli hesaplamalar yapmasına ve adaletli olup olmadığı konusunda düşünmeye teşvik etmede güçlü ve kritik bir araçtır. Çünkü sinik tüketici kendisinin markalar tarafından bir av olarak görüldügünü düşünmektedir (Berdysheva ve Romanova, 2017, s.400). Fiyat uygulamalarının tüketicide sinik davranışlara yol açıp açmadığı konusunda, fiyat ile ilgili şeffaflığın oluşmadığı durumlarda tüketiciler sinik davranış eğilimi gösterebilmekte ve bunu da boykot ederek ortaya koymakta, satın alma eylemlerini 
azaltmaktadır. Buna karşın fiyat konusunda gerekli şeffaflık oluşturulabilirse, fiyat prosedürlerinin adil olduğuna inanılırsa tüketici sinizmi ve boykot yapmaya yönelik tutum azalabilmekte, dolayısıyla tüketicilerin satın alma niyeti de olumlu yönde değişmektedir (Atılgan vd., 2017, s.41). Dünya genelinde dahi bakıldığında markaların tüketici yararına katkı yapmadığı, tüketicilerin iyi niyetlerini suistimal ettiği ve bundan dolayı da memnuniyetsizlik duyduğu gözlenmektedir ve bu durum yapılan araştırma ile de kamuoyunda yaygın bir şekilde olduğunu göstermektedir (Amezcua ve Quintanilla, 2016, s.291). Tüketici sinizmi; markaların pazarlama iletişimi konusundaki ikna girişimlerini etkisiz hale getirmek ve markayı kınamak için yapılan retorik bir saldırıdır ve genelde belli bir mal ya da hizmetle ilgili sorun yaşayan kullanıcıların yarattığı negatif (markaya karşı negatif) davranışlarıdır (Chang vd., 2011, s.489).

Tüketici sinizminin; pazarlara ve pazarlama kurumuna karşı tüketici direncinin bir biçimini temsil ettiğini iddia etmek hiç de yanlış olmaz. Misal Noel'e karşı sinik davranışlar gösteren tüketiciler Noel'in ticarileştirildiği, materyalistleştirildiği ve böylece Noel'in anlamının yok edildiğini, Noel geleneğine aykırı davranıldığını belirtmişlerdir (Mikkonen vd., 2011, s.111). Pazara yönelik sinizmde; tüketiciler, markalara ve markaların ahlakı konusunda bir güvensizlik sergilemektedir ve tüketiciler böyle bir durumda işletmelerin ikna çabalarına karşı bilişsel bir koruma aracı olarak sinik davranış göstermektedirler (Bertilsson, 2015, s.454). Dolayısıyla tüketicilerin sinik davranışları aynı zamanda da bir tüketici ahlakı olarak da gelişim göstermektedir. Araştırma bulguları; tüketici ahlakı ile tüketici sinizminin ilişkili olduğunu ortaya koymuştur (Bertilsson, 2015, s.461). Benzer bir şekilde Chowdhury ve Fernando (2014) empati, ahlak ve sinizm kavramlarının, tüketicinin etik inancı ile ilişkisini incelemiş ve bahsi geçen ilişkileri sınamak amaciyla 8 hipotez geliştirmişlerdir. Sınama sonucunda da 8 hipotezin 6'sında ilişki tespit etmişlerdir. Bir başka anlatımla tüketici sinizmi ile tüketici etiği arasında bir ilişki mevcut olduğu görülmüştür.

Bir tüketicinin uğradığı haksızlık, diğer tüketicilerinde sinik davranışlarını arttırmakta ve bu da satın alma eğilimlerine yansımaktadır. Ayrıca bu etki sadece prososyal (bir başkasının iyiliğini gözeterek yardım etme, paylaşma, işbirliği yapma, empati kurma, koruma, rahatlatma, teselli etme, dahil etme gibi davranışlar) bir değer yönelimine sahip tüketiciler 
için değil, kendi kendine yönelime sahip tüketiciler için de gerçekleşir (Van Dolen, 2012, s.314).

Sinik tüketiciler; markaların kendileriyle ilgilenmek, ihtiyaç ve isteklerine karşılık vermek gibi görevleri varken, bu konularla çok az ilgilenildiğini ve bunun yerine tek dertlerinin kendi çıkarlarını korumak olduğunu düşünmektedir. Bunun sonucu olarak da tüketiciler haksızlık, sahtekârlık, samimiyetsizlik gibi davranışlar ile karşılaştıkları deneyimler yaşadıklarını belirtmektedirler. Bundan dolayı da tüketicilerde sinik tutumlarının daha da geliştiği iddia edilebilmektedir ( Akgüç Çetinkaya ve Ceng, 2018, s.171). Bu çerçevede yaygın bir biçimde uygulanan bir alışveriş sezonu etkinliği olarak black friday (Kara Cuma) etkinliğine ilişkin Türkiye'deki tüketicilerin duygu ve tutumlarını tüketici sinizmi bağlamında değerlendirmek amaciyla twitter üzerinden duygu analizi çalışması yapılmıştır. Genel olarak tüm dünyada olumlu bir yaklaşımla değerlendirilen bu sezon etkinliğinin Türkiye'de genel olarak, özellikle de sosyal medyaya, olumsuz bir biçimde yansıdığı gözlemlenmiştir. Bunun sebebi olarak black friday tabirinin "Kara Cuma" manasına gelmesinin etkisi büyüktür. Bundan dolayı da sinik tüketici davranışlarıyla karşılaşmamak için markalar "Efsane Cuma" ve "Hayırlı Cumalar" gibi kampanya isimlendirmeleri yaparak tüketicilerden olumlu tepkiler almış ve sinik etkiyi kırmışlardır (Akgüç Çetinkaya ve Ceng, 2018, s.178).

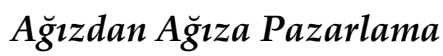

Ağızdan ağıza pazarlama bir tüketicinin ticari olarak algılanan bir marka, mal ya da hizmetle ilgili olarak başkalarıyla konuştuğu kişiler arası iletişimdir. Ağızdan ağıza pazarlama, sadece bir ürün veya marka hakkında olumlu ya da olumsuz önerilerde bulunmakla kalmamakta, aynı zamanda ürün ya da markayla ilgili tartışma ve paylaşmayı da içermektedir (Liv vd., 2019, s.15). Tüketiciler olumlu ya da olumsuz deneyimleri neticesinde yaşadığı gerginliği azaltmak istemesi dolayısıyla deneyim ve bilgi birikimini diğer tüketicilerle paylaşır. Bu paylaşım ile kendi görüşlerine katılan başka tüketiciler olup olmadığını bilmek isterler ve var ise desteklendiğini görmekten mutlu olurlar. Bunu yanı sıra; iletişim sürecine dâhil olanların ilgisini çekebilme isteği, belli konulardaki uzmanlığını ispat etme düşün- 
cesi, başkalarıyla iletişim kurabilme ve bu iletişimi kalıcı ilişkilere dönüştürebilme arzusu sebebiyle de ağızdan ağıza pazarlama yapmaktadırlar (Silverman, 2007, s.171-172).

Ağızdan ağıza pazarlamanın önemi iş dünyası tarafından iyi bilinmektedir. Çünkü ağızdan ağıza pazarlama kanalı tüketiciler için diğer pazarlama iletişimi araçlarından daha güvenilirdir ve bundan dolayı da en etkili iletişim kanallarından biridir. Gelişen teknoloji ile ağızdan ağıza iletişim kanalları daha da gelişmekte (sanal ortamlardaki tüketici yorumları gibi) ve bundan dolayı da tüketici üzerindeki etkisinin artacağı ortamlar daha da artmaktadır. Bahsi geçen ortamların artmasından dolayı da ağızdan ağıza pazarlamanın etkisinin artmaya devam etmesi beklenmektedir. Ağızdan ağıza pazarlamanın reklam ve diğer pazarlama iletişimi araçlarından daha ikna edici olabildiği araştırmalarla görülmüsstür. Çünkü tüketiciler tarafından ağızdan ağıza pazarlama ile elde edilen bilgiler genelde doğru çıkmaktadır (Park vd., 2018, s.305). Bu araştırmayı destekleyecek bir başka araştırmada tüketicilerin en çok etkilendiği pazarlama iletişimi aracı \%45,5 ile ağızdan ağıza pazarlama ve en çok tavsiye aldığı ortamda \%23,7 ile kişiler arası iletişim, tüketicilerin en çok etkilendiği tavsiye ortamı da \%36,2 ile yine aynı şekilde kişiler arası iletişimdir. Ağızdan ağıza pazarlama; reklam, halka benimsetme, kişisel satış, satış geliştirme, doğrudan pazarlama, sponsorluk, fuarcılık, e-ticaret, ambalaj, satış yeri uygulamaları, amaca yönelik pazarlama, etkinlik pazarlaması gibi diğer pazarlama iletişimi araçları ile kıyaslandığında tüm bu pazarlama iletişim araçlarından daha etkili olduğu, kendisine en yakın pazarlama iletişimi aracının satış geliştirme olduğu görülmüş̧ür (Göktaş ve Erdoğan Tarakçı, 2018, s.1024-1026).

Turizm sektörü üzerine yapılan bir araştırmada ağızdan ağıza pazarlamanın müşteri sadakati yarattığı görülmüştür. Ağızdan ağıza pazarlamada kritik nokta müşteri memnuniyeti yaratılmasıdır. Konuk memnuniyeti ve sadakati yaratılması da işletme karlılığını arttıracaktır. Dolayısıyla ağızdan ağıza pazarlamanın etki zinciri memnuniyet - sadakat - karlılık şeklindedir ve bu üçlü için bir arabulucu rolü vardır (Matzler vd., 2019, s.454). Ağızdan ağıza pazarlamanın tüketicilerin satın alma davranışı ve ürün satışları üzerindeki etkisine ilişkin bir çok ampirik çalışma bulunmaktadır. Özellikle çevrimiçi ortamlardaki (bunlar içinde de bilhassa sosyal medya) ağızdan ağıza pazarlama ürünün yayılmasını sağlamaktadır 
(Zhen, vd., 2019, s.364). Mobil bankacılık uygulamaları üzerine yapılan bir araştırmada da ağızdan ağıza pazarlamanın kullanıcı tutumlarını etkilemede ana unsur olduğu sonucu çıkmıştır. Ağızdan ağıza pazarlama mobil bankacılığın benimsenmesinde olumlu bir etkiye sahiptir (Mehrad ve Mohammadi, 2017, s.1360).

Kurumlar tarafından bir sosyal medya aracı olarak kullanılan mikrobloglarda ağızdan ağıza pazarlama aracı olarak kullanılmaktadır. Mikrobloglar içerisinde de hızlı yükselişi göz önüne alındığında en etkili ve popüler olan çevrimiçi ağızdan ağıza pazarlama aracı Twitter'dır. Twitter'da bireyler, sosyal ağın diğer üyelerini etkileyen görüş ve duygularını ifade ettiklerinde ortaya etkin bir ağızdan ağıza pazarlama ortamı çıkmaktadır. Burada çok sayıda kişinin anında erişebileceği mal ve hizmetler hakkında çevrimiçi yapılan olumlu veya olumsuz ifadelere rastlanmaktadır (Aroean vd., 2019, s.325). Tüketicilerin sosyal ağlarda tartışması veya ürün göstermesi marka bilinirliğini arttırmakta ve istemeden de olsa bu nesneleri satın almaya ikna edebilmektedir. Ağızdan ağıza pazarlama tartışmaları sayesinde, bir şekilde marka algısı ve satış hacmi yükselebilir, yeni ürünlerin yayılmasını teşvik edebilir ve sonuç olarak işletmelerin kar ve pazar rekabetçiliğini de arttırabilmektedir (Liv vd., 2019, s.15).

\section{Yöntem}

\section{Araştırmanın Amacı, Yöntemi ve Kısıtları}

Tüketici sinizmi önceden de bahsedildiği gibi markaların sunduğu vaatler ile müşteri beklentilerinin kesişmemesinden dolayı, tüketicinin markalara karşı duyduğu hayal kırıklığı, güvensizlik, şüphe etme, aldatılma gibi düşüncelere sahip olması ve bu davranışları da; daha sonraki satın alma, değerlendirme aşamalarında da sergilemesidir. Sinik olan tüketicilerin doğal olarak bu tarz davranışların belli ettiği hallerin de oluşması beklenmektedir. Bu beklentilerden birinin de sinik tüketicilerin diğer tüketicilerle konuşması, önerileriyle onları etkilemeye, gözlerini açmaya yönelik eylemler gerçekleştirmedir. Ayrıca sinik tüketicilerin, diğer tüketiciler bir marka hakkında kendileriyle konuştuklarında da kuşku içerisinde olaya yaklaşmaları da beklenmektedir. Bir tüketicinin diğer tüketicilerle konuş- 
tuğu (örneğin bir marka ya da ürün hakkında olumlu veya olumsuz konuştuğu) çabalara pazarlama disiplininde "ağızdan ağıza pazarlama" denmektedir. İşte eldeki bu çalışma ile öncelikle tüketicilerin ne derece sinik tutumlar sergilediği ve sinik tutuma sahip bir tüketicinin tavsiye alan bir kişi olarak ağızdan ağıza pazarlama çabaları içerisinde ne ölçüde dahil olabildiği, ne derece etkilendiğinin tespit edebilmesi amaçlanmaktadır. Bunun için de öncelikli olarak katılımcılar sinik bir tutuma sahip olup olmadığı belirlenmeye çalışılmıştır, sonrada eğer katılımcılar sinik tutumlar sergilemekteyse ağızdan ağıza pazarlama davranışları karşılaştıklarında sinik bir tutum içerisine ne kadar düşmektedirler konusu da belirlenmeye çalışılmıştır. Böylece Türkiye'de hakkında çok az çalışma yapılan ve bunların hiçbiri de (tespit edildiği kadarıyla) ağızdan ağıza pazarlamayla olan ilişkisi üzerine olmayan tüketici sinizmi alanyazınına katkı sunmak amaçlanmıştır.

Yukarıda belirtilen araştırma amacı konusuna yanıt bulabilmek niyetiyle bir anket hazırlanarak "kolayda örnekleme yöntemi" ile 575 kişiye ulaşılmış ve bu kişilerin inceleme sonucu 476's (eksik, kusurlu anketlerin elenmesi sonucu) değerlendirmeye alınmış, 99'u hariç tutulmuştur. Anket iki bölüm halinde hazırlanmış olup, ilki demografik sorularken, ikincisi ölçek önermelerdir. Ölçek önermelerde kendi içerisinde iki bölümden oluşmaktadır. İlki "tüketici sinizmi ölçeği” olup Helm, Moulard ve Richins tarafından 2015 yılında geliştirdikleri, 8 önermeden oluşan ve aynı adı (tüketici sinizmi ölçeği) taşıyan ölçektir. İkincisi ise "ağızdan ağıza pazarlama ölçeği" olup Gürcü (2018) ve Akdoğan'nın (2015) çalışmalarından yararlanılmış olup, araştırmacıların kullandıkları ölçek tüketici sinizmi ölçeğine uyumlu olacak şekilde tasarlanmıştır ve ortaya "ağızdan ağıza pazarlama ölçeği" için 34 önerme çıkmıştır.

Ölçek önermeleri aslına uygun biçimde 5'li Likert ölçeğinde olduğu gibi (1: Kesinlikle Katılmıyorum, 2: Katılmıyorum, 3: Fikrim Yok, 4: Kat1lıyorum, 5: Kesinlikle Katılıyorum) hazırlanmış ve ölçekte yedi ifade tersten sorulmuştur. Böylece anket 6 demografik ve 42 ölçek ifadeler olmak üzere katılımcılara toplamda 48 adet olarak yöneltilmiştir. Önermeler sunulurken tüketici sinizmi ölçeğindeki ters önermeler yine aynı şekilde tersten sunulmuşken; ağızdan ağıza pazarlama ölçeğindeki önermelerin de 26. önerme ve faktör analizi sonucu oluşturulan "tavsiyenin şüpheye düşürücülüğ̈̈̈" ile "memnuniyetsizlik ve onaylamama" faktörlerinde de 
çoğu önerme tersten yöneltilmiştir. Tersten yöneltilen önermeler ile araştırmanın güvenilirliği daha da artmaktadır. Anket 11 Nisan-1 Mayıs 2019 tarihleri arasında www.surveey.com web sitesi üzerinden linkin dağıtılması şeklinde çevrimiçi olarak uygulanmış olup, SPSS 25 paket programinda sinamaya tabi tutulmuştur.

Araştırmanın yukarıda bahsi geçen amaca ulaşmasının önünde bazı kısitlar mevcuttur. Örneğin veri toplama yönteminin "kolayda örnekleme yöntemi" olması bir kısıt olarak görülebilir ve araştırma amacını tam olarak ortaya koyacak bir yöntem olmadığı düşünülebilir. Ancak katılımc1lara daha kolay ulaşmak açısından ve maddi açıdan daha az yük olmasından dolayı bu yöntem seçilmiştir. Sonuçlarda dolayısıyla bu yöntemin uygulandığı dikkate alınarak değerlendirilmiştir. Bunun yanı sıra örneklem sayısı da bir kısıt olarak görülebilir (476 örneklem). Daha fazla katılımcı ile daha farklı ya da daha tutarlı sonuçların alınabilme olasılığı her zaman bulunmaktadır. Başka bir kısıt olarak da tüketicilerin anketi yanıtlarken belli bir marka üzerinden yorumlama yapılması değil, genel olarak yorumlaması istenmiştir. Eğer belli bir marka sunulsa ve sunulan marka ile ilgili bir araştırma yapılmış olsa daha farklı sonuçlar çıkabilecektir. Son kısıt olarak da "ağızdan ağıza pazarlama ölçeği" hazır tek bir ölçek değil, farklı araştırmacılardan alınarak "tüketici sinizmi ölçeği" ile uyumlu hale getirilerek uygulanmıştır. Bunun yerine "tüketici sinizmi ölçeği" ile gerçekleştirilerek uyumu sınanmış bir ölçek kullanılabilirdi. Ancak böyle bir ölçek Türkiye'deki çalışmalarda olmadığından ve Türkiye dışında yapılan çalışmalarda da kullanılan ölçekler tam olarak çalışma metni içerisinde gösterilmediğinden araştırmacı tarafından böyle bir uyarlama yoluna gidilmiştir.

\section{Araştırmanın Hipotezleri}

Araştırmanın konusu önceden de belirtildiği gibi tüketici sinizmi kavramı ile ağızdan ağıza pazarlama kavramı arasındaki ilişkiyi tespit edebilmektir. Aslında burada esas sınanacak olan iki kavram arasındaki ilişkiden ziyade sinik tüketicilerin ağızdan ağıza pazarlama eylemlerinden ne derece etkilendiğidir. Bunun içinde her iki kavrama ilişkin ölçeklerden faydalanılmıştır. Tüketici sinizmi ölçeği aslına uygun olarak tek faktör şeklinde sınamaya sokulmuşken, ağızdan ağıza pazarlama ölçeği için faktör analizi 
gerçekleştirilmiştir ve ortaya çıkan faktörler üzerinden (6 faktör) sinamalar yapılmıştır. Bundan dolayı da bahsi geçen etki düzeyini tespit edebilmek amacıyla oluşturulan araştırmanın temel hipotezleri de aşağıdaki gibi (yokluk ya da sıfır hipotezi ve alternatif hipotez) olmuştur.

- H0a: Katılımcilar sinik tutumlar göstermemektedir.

- H1a: Katılımcilar sinik tutumlar göstermektedir.

- H0b: Sinik bir tüketici ağızdan ağıza pazarlama faaliyetlerinden etkilenmemektedir.

- H1b: Sinik bir tüketici ağızdan ağıza pazarlama faaliyetlerinden etkilenmektedir.

\section{Araştırmanın Güvenilirliği}

Bir ölçeğin güvenilirlik katsayısının $0,80-1,00(0,80 \leq \alpha \leq 1,00)$ arasında olması ölçeğin yüksek düzeyde güvenilir olduğunu göstermektedir (Kılıç, 2016: 48). Araştırmada iki farklı ölçek kullanılmıştır. Bunlardan ilki "tüketici sinizmi" ölçeği olup, ölçekteki 8 önerme için Cronbach's Alpha katsayısı 0,806'dır. İkincisi ise "ağızdan ağıza pazarlama" ölçeği olup, ölçekteki 34 önerme için Cronbach's Alpha katsayısı 0,906'dır. Sonuçlara göre her iki ölçeğinde güvenilirliği yüksek düzeydedir. Söz konusu sınamaya ilişkin sonuçlar aşağıdaki Tablo 1'de gösterilmektedir.

Tablo 1: Ölçeklerin Güvenilirliği İstatistikleri

\begin{tabular}{lll}
\hline Ölçek & Cronbach's Alpha & Önerme sayısı \\
\hline Tüketici Sinizmi &, 806 & 8 \\
\hline Ağızdan Ağıza Pazarlama &, 906 & 34 \\
\hline
\end{tabular}

\section{Temel Bileşenler (Faktör) Analizi}

Temel Bileşenler (Faktör) analizi öncesi ölçeğin sinamaya uygun olup olmadığını görebilmek amacıyla Bartlet'in küresellik testi ve KMO (KaiseMeyer-Olkin) testi gerçekleştirilmiştir. Sınama sonucunda "tüketici sinizmi" ölçeği için KMO değeri 0,790, Bartlet'in küresellik testi 1314,958 ve p değeri 0,000'dır. Bu sonuçlara göre de "tüketici sinizmi" ölçeğinin (KMO değeri 0,60 'dan büyük olduğu için) örneklem büyüklüğü yeterlidir ve 
Bartlet'in küresellik testi sonucu p>0.05 olduğu için veriler birbiri ile ilişkilidir. Bu durumda faktör analizi yapılabilmektedir ve gerçekleştirilen faktör analizi sonucunda orijinaline uygun bir şekilde tek bir faktör meydana gelmiştir. "Tüketici sinizmi" ölçeği toplam varyansın \%60,147'sini açıklamaktadır. Ağızdan ağıza pazarlama ölçeği için ise; KMO değeri 0,807 ve Bartlet'in küresellik testi yaklaşık ki kare değeri 9295,468' dir. Ayrıca Bartlet'in küresellik testi $\mathrm{P}$ değeri de 0,000 'dır. Bu sonuçlara göre "ağızdan ağıza pazarlama" ölçeği için faktör analizi yapılabilmektedir ve gerçekleşen faktör analizi sonucunda ortaya 6 faktör çıkmıştır. Bu faktörlere sırasıyla; "kaynağın uzmanlığı", "tavsiyenin aldatılmayı azaltması", "tavsiyeye güven", "tavsiyenin etkisi", "tavsiyenin şüpheye düşürücülüğü", "memnuniyetsizlik ve onaylamama" adları verilmiştir. Faktörlere bu adlar verilirken Helm'in 2006 yılındaki çalışması dikkate alınmıştır. “Ağızdan ağıza pazarlama" ölçeği toplam varyansın \%69,126'sını açıklamaktadır.

Tablo 2: "Tüketici Sinizmi" Ölçeği İçin KMO ve Bartlet'in Küresellik Testi Sonucu

\begin{tabular}{lll}
\hline Kaiser-Meyer-Olkin Örneklem Yeterliliğinin Ölçümü. &, 790 \\
\hline \multirow{3}{*}{ Bartlett'in Küresellik Testi } & Yaklaşık Ki Kare & 1314,958 \\
\cline { 2 - 3 } & Serbestlik Derecesi & 28 \\
\cline { 2 - 3 } & P Değeri &, 000 \\
\hline
\end{tabular}

Tablo 3: "Ağızdan Ağıza Pazarlama" Ölçeği İçin KMO ve Bartlet'in Küresellik Testi Sonucu

\begin{tabular}{lll}
\hline \multicolumn{2}{l}{ Kaiser-Meyer-Olkin Örneklem Yeterliliğinin Ölçümü. } &, 807 \\
\hline \multirow{3}{*}{ Bartlett'in Küresellik Testi } & Yaklaşık Ki Kare & 9295,468 \\
\cline { 2 - 3 } & Serbestlik Derecesi & 561 \\
\cline { 2 - 3 } & P Değeri &, 000 \\
\hline
\end{tabular}

\section{Bulgular}

Araştırmada amaca uygun bulguları elde etmek ve bu bulguların demografik özelliklere göre farklılık gösterip göstermediğini görebilmek amacıyla bazı sınamalar gerçekleştirilmiştir. Örneklem için gerçekleştirilen normallik sınamasında $p$ değeri 0,000 olup normal dağılıma uygun olmadığı sonucu çıkmıştır. Böyle bir durumda nonparametrik sınamaların yapılması gerektiğine dair görüşler olmakla birlikte 30 ve üzeri örneklemler 
için (ki bazı kaynaklarda bunun 50 ve üzeri olduğu da söylenmektedir) parametrik sınamaların daha gerçekçi sonuçlar verdiği de belirtilmektedir.

Burada hangi testlerin (parametrik ya da nonparametrik) yapılması gerektiğine dair ikinci bir öneri de çarpıklık ve basıklık katsayılarıdır. Anket ile ilgili çarpıklık ve basıklık katsayısının kim kaynaklarda değerlerinin 1,5 ile $+1,5$ arasında olması, bazı kaynaklarda ise -2 ile +2 arasında olmasının örneklemin normal dağılıma uygun olduğunun varsayılması için yeterli olduğuna dair iddialar hakimdir ve böyle bir durumda ise parametrik sınamaların yapılması gerektiği vurgulanmaktadır (Demir vd., 2016: 133). Eldeki araştırmada da sunulan bu veriler neticesinde parametrik testlerin yapılması gerektiği kanısına varılmıştır ve parametrik testler uygulamaya konmuştur.

Araştırmada öncelikle katılımcılara yönelik demografik bulgular sunulmakta, sonrasında ise hipotez sinamaları yapılmaktadır. Yapılacak olan "tek örneklem $t$ testi", "bağımsız örneklem $t$ testi", "tek yönlü varyans analizi", "korelasyon" ve "regresyon" analizleri için yokluk (H0) ya da alternatif (H1) hipotezler sunulmakta ve yokluk (H0) hipotezinin kabul ya da reddedilebilirliğine ilişkin yorumlamalar yapılmaktadır.

\section{Demografik Bulgular}

Araştırmaya katılım sağlayan 476 kişiye ait demografik özelliklere göz gezdirildiğinde kadınların oranı $\% 38,7$ ve erkeklerin oranı $\% 61,3$ tür. Katılımcıların \%31,1'i evli; \%68,9'u bekardır. Katılımcıların \%56,3'ü 18-24 yaş aralığında; \%72,3'ü üniversite eğitim seviyesinde; \%49,6's1 öğrenci ve $\% 25$,2'si £2021-4000 arası gelire sahiptir. 
Tablo 4: Katılımcıların Demografik Özellikleri

\begin{tabular}{|c|c|c|c|}
\hline Değişken & Gruplar & Frekans & $\%$ \\
\hline \multirow{2}{*}{ Cinsiyet } & Kadın & 184 & 38,7 \\
\hline & Erkek & 292 & 61,3 \\
\hline \multirow{2}{*}{$\begin{array}{l}\text { Medeni } \\
\text { Hal } \\
\end{array}$} & Evli & 148 & 31,1 \\
\hline & Bekar & 328 & 68,9 \\
\hline \multirow{6}{*}{$\begin{array}{l}\text { Yaş } \\
\text { Aralığı }\end{array}$} & 17 Ve Alt1 & 4 & 8 \\
\hline & $18-24$ & 268 & 56,3 \\
\hline & $25-34$ & 108 & 22,7 \\
\hline & $35-44$ & 88 & 18,5 \\
\hline & $45-54$ & 8 & 1,7 \\
\hline & +55 & 0 & 0 \\
\hline \multirow{4}{*}{$\begin{array}{l}\text { Eğitim } \\
\text { Durumu }\end{array}$} & İlkokul & 4 & 8 \\
\hline & Lise & 40 & 8,4 \\
\hline & Üniversite & 344 & 72,3 \\
\hline & Lisansüstü & 88 & 18,5 \\
\hline \multirow{9}{*}{ Meslek } & Emekçi (İşçi- Çiftçi) & 16 & 3,4 \\
\hline & Memur & 52 & 10,9 \\
\hline & Öğrenci & 236 & 49,6 \\
\hline & Ev Kadını & 12 & 2,5 \\
\hline & Yönetici & 12 & 2,5 \\
\hline & $\begin{array}{l}\text { Uzman (Akademisyen,Dr., } \\
\text { Mühendis, Avukat Vs.) }\end{array}$ & 84 & 17,6 \\
\hline & Esnaf-Tüccar & 16 & 3,4 \\
\hline & İşsiz & 12 & 2,5 \\
\hline & Diğer & 36 & 7,6 \\
\hline \multirow{6}{*}{$\begin{array}{l}\text { Hane Gelir } \\
\text { Durumu (E) }\end{array}$} & $2020^{\prime}$ Den $\mathrm{Az}$ & 104 & 21,8 \\
\hline & 2020 & 60 & 12,6 \\
\hline & $2021-4000$ & 120 & 25,2 \\
\hline & 4001-6000 & 80 & 16,8 \\
\hline & $6001-8000$ & 32 & 6,7 \\
\hline & 8001 Ve Üstü & 80 & 16,8 \\
\hline
\end{tabular}

\section{Grup Ortalamaların Karşılaştırılması}

Tüketici sinizmi ve ağızdan ağıza pazarlama ölçeklerine ilişkin önermelerin faktörlerinin ortalamalarının belirlenmesi için tek bir grup olduğundan "tek örneklem t test" uygulanmıştır. Katılımcıların demografik özellikler bakımından gruplar arasında anlamlı bir farklılığa sahip olup olmadıkların belirleyebilmek maksadıyla da iki gruptan oluşan değişkenlerde "bağımsız örneklem $t$ test" ve en az üç gruptan oluşan değişkenlerde "tek yönlü varyans analizi" uygulanmıştır. 


\section{Tek Örneklem T Test}

Tek örneklem $t$ testi ile faktörlerin ortalamasını 3 değerinden (fikrim yok seçeneği) büyük olup olmadığını sınamaya yönelik bir testtir. Tüketici sinizmi faktörünün ortalamasının 3 değerinden daha fazla olması tüketicilerin sinik tutum ve davranışlar içerisinde olduğuna işaretken; ağıdan ağıza pazarlama ölçeği faktörlerinin 3 değerinden büyük olması sinik tüketicilerin ağızdan ağıza pazarlama eylemlerinden etkilendiği ve sinik davranışların daha da şiddetlendiği anlamına gelmektedir. Çalışmada, bahsi geçen faktörler ortalamasına ve diğer sınamalara göre bu şiddet derecesi ile ilgili çıkarımlar yapılmaktadır. Tek örneklem $t$ testi için hipotezler aşağıdaki gibidir.

- Ho: $\mu \leq 3$ (Faktörlerin ortalaması 3 değerine eşit ya da 3 değerinden küçüktür)

- H1: $\mu>3$ (Faktörlerin ortalaması 3 değerinden büyüktür)

Aşağıdaki Tablo 5'te görülmektedir ki; "kaynağın uzmanlığı" faktörü hariç diğer tüm faktörlerde ortalamalara ilişkin değer 3 rakamından büyüktür ve p değerleri 0,000'dır. Buna göre "kaynağın uzmanlığı" faktörü için H0 hipotezi reddedilemezken; diğer tüm faktörler için reddedilebilmektedir. Ağızdan ağıza pazarlama faktörlerinin ortalamalarında dikkat çeken durum katılımcıların "kaynağın uzmanlığı" faktörü karşısında yansız (nötr) olması (ortalaması tam 3) ve diğer faktörlerin de ortalamasının 3 rakamından çok az büyük olmasıdır (en büyük ortalama 3,3121 değerine sahiptir).

Tablo 5: Tek Örneklem T Testi Sonuçları

\begin{tabular}{lllll}
\hline Faktör & N & Ortalama & T değeri & P değeri \\
\hline Tüketici sinizmi & 476 & 3,6607 & 21,647 &, 000 \\
\hline Kaynağın uzmanlı̆̆ı & 476 & 3,0000 &, 000 & 1,000 \\
\hline Tavsiyenin aldatılmayı azaltması & 476 & 3,1754 & 6,435 &, 000 \\
\hline Tavsiyeye güven & 476 & 3,2759 & 8,925 &, 000 \\
\hline Tavsiyenin etkisi & 476 & 3,2437 & 6,264 &, 000 \\
\hline Tavsiyenin şüpheye düşürücülüğ̈u & 476 & 3,1277 & 3,658 &, 000 \\
\hline Memnuniyetsizlik ve onaylamama & 476 & 3,3121 & 9,126 &, 000 \\
\hline
\end{tabular}


Tüketici sinizmi ölçeğine ait önermelerin ortalamalarına bakıldığında 4,04 ile en yüksek ortalamaya "markaların çoğu tüketicilere hizmet etmekten çok kar etmekle ilgilenirler" önermesi; 3,13 ile en düşük ortalamaya "markalar ürünlerini satın aldığımın sonrasında ne olacağını umursamamaktadırlar" önermesi gelmektedir. Tüketici sinizmi ölçeğine ait önermelerin ortalamasını gösteren tablo aşağıdaki "Tablo 6" başlığı altında sunulmuştur. "Ağızdan ağıza pazarlama" ölçeğinde çok fazla önerme olduğu için "tüketici sinizmi" ölçeğinde olduğu gibi tek tek önermeler yorumlanmamış, gerekli yorum faktörler üzerinden yapılmıştır.

Tablo 6: Tüketici Sinizmi Ölçeği Önermelerinin Ortalaması

\begin{tabular}{lll}
\hline Önermeler & N & Ortalama \\
\hline $\begin{array}{l}\text { Markaların çoğu kanunları çiğnemeyi umursamamakta; para } \\
\text { cezaları ve davaları da iş yapmanın maliyeti olarak görmektedirler. }\end{array}$ & 3,29 \\
\hline Markaların coğu tüketicilere hizmet etmekten cok kar etmekle & 476 & 4,04
\end{tabular}

Markalarm çoğu tüketicilere hizmet etmekten çok kar etmekle 476 4,04 ilgilenirler.

Markalar tüketicileri manipüle edilebilecek kuklalar olarak $\quad 476$ 3,50 görmektedirler.

Markalar ürünlerini satın aldığımın sonrasında ne olacağını $\quad 476$ 3,13 umursamamaktadırlar.

Eğer paramın karşılığını almadı̆̆ımı düşünüyorsam, markanın 476 4,09 bana söylediklerine inanmam.

Markaların çoğu kar elde edebilmek için her şeyi feda etmektedir. 476 3,61

Markaların çoğu kar elde edebilmek için ellerinden geleni yapma 476 3,94 isteği duymaktadırlar.

Markaların çoğu kar marjını iyileştirmek için ellerinden geleni $\quad 476$ 3,67 ardına koymamaktadır.

Yukarıdaki tablolarda ortalamaları verilen "tüketici sinizmi" ve "ağızdan ağıza pazarlama" ölçekleri faktörlerine göre; "tüketici sinizmi" ölçeği ortalaması da 3,6607 değere sahiptir ve bu değer ile 4 ile kodlanan "katıllyorum" seçeneğinin altındadır. Bu ortalamaya göre katılımcıların azda olsa sinik tutum ve/veya davranışlara sahip olduğu söylenebilmektedir. "Ağızdan ağıza pazarlama" ölçeği faktörlerinin ortalamasına bakıldığındaysa; faktörlerden birinin (kaynağın uzmanlığı faktörü) ortalamasının 3,0000 olduğu; en yüksek ortalamanın 3,3121; en düşük ortalamanın 3,1277 olması sebebiyle katılımcıların "ağızdan ağıza pazarlama” ölçeği 
faktörlerine yönelik bakış açısı (ki bu ölçeğin önermeleri tüketicilerin ağızdan ağıza pazarlama faaliyetlerinden ne derece etkilenerek sinik davranış gösterebileceğini tespit etmeye yönelik önermelerden oluşmaktadır) 3 değerinden biraz üstte olduğundan katılımcların ağızdan ağıza pazarlama (tavsiye) eylemlerinden az da olsa etkilenerek sinik davranışlar sergileyebileceğine işarettir. Araştırmada kullanılan iki ölçek arasındaki etki boyutunu görebilmek için araştırmanın ilerleyen bölümlerinde "regresyon" analizi yapılmıştır.

\section{Bă̆ımsız Örneklem T Test}

Araştırma katılımcıların görüşlerinin "cinsiyet" ve "medeni hal" değişkenlerindeki gruplar arasında anlamlı bir farklılık olup olmadığını tespit edebilmek için "bağımsız örneklem $t$ testi" uygulanmıştır. Testin hipotezleri aşağıda görüldüğü gibi "varyansların eşit olup olmadığına yönelik hipotezler" ve "grup ortalamaları arasında farklılık olup olmadığına yönelik hipotezler" şeklindedir.

Varyansların eşit olup olmadığına yönelik hipotezler;

- $\mathrm{H}_{0}: \sigma_{1}^{2}=\sigma_{2}{ }^{2}$ (Varyanslar birbirine eşittir)

- $H_{1}: \sigma 1^{2} \neq \sigma_{2}{ }^{2}$ (Varyanslar birbirine eşit değildir)

Grup ortalamaları arasında farklılık olup olmadığına yönelik hipotezler;

- $\mathrm{H}_{0}: \mu 1=\mu 2$ (Faktörlere yönelik tüketici tutumlarında, değişkenlere ait gruplar arasında anlamlı bir farklılık bulunmamaktadır)

- $\mathrm{H}_{1}: \mu 1 \neq \mu 2$ (Faktörlere yönelik tüketici tutumlarında, değişkenlere ait gruplar arasında anlamlı bir farklılık bulunmaktadır)

Tablo 7'de görüldügü gibi "tavsiyenin şüpheye düşürücülüğü" faktöründe Levene Testi P Değeri 0,001 olup bu faktör için varyansların eişt olmadığ 1 görülmekteyken; diğer tüm faktörlerde $p>0,05$ olup bu faktörlerde varyanslar eşit dağılmaktadır. Bundan dolayı da "tavsiyenin şüpheye düşürücülüğ̈̈" faktöründe varyansların eşit olup olmadığına yönelik hipotezlerden H0 hipotezi reddedilebilmektedir; fakat diğer faktörlerde reddedilememektedir. Varyansların hangi faktörlerde eşit, hangilerinde değil konusu açıklığa kavuşturulduktan sonra T Testi P Değeri sonuçlarına bakıldığında ise; "tüketici sinizmi", "tavsiyenin şüpheye düşürücülüğ̈̈" ve "memnuniyetsizlik ve onaylamama" faktörlerinde $p<0,05$ 
olduğu görülmekte ve dolayısıyla da bu üç faktörde H0 hipotezi reddedilebilmektedir. Bir başka anlatımla bahsi geçen üç faktörde gruplar arasinda (kadın ve erkek) anlamlı bir farklılık bulunmaktadır. Ortalamalara göz gezdirildiğinde "tüketici sinizmi" faktöründe erkeklerde (erkek=3,7568 ve kadın=3,5082) , "tavsiyenin şüpheye düşürücülüğ̈̈" (ka$\mathrm{d}_{1 \mathrm{n}}=3,2478$ ve erkek=3,0521) ve "memnuniyetsizlik ve onaylamama" (ka$\mathrm{d} ı n=3,4752$ ve erkek=3,2094) faktörlerinde ise kadınlarda ortalamaların daha fazla olduğu görülmektedir. Buradan yola çıkarak erkeklerin daha sinik tutumlar sergilediği; fakat buna karşın ağızdan ağıza pazarlama eylemleri karşısında kadınların daha fazla etkilenerek sinik tutumlar sergileyebileceği sonucu çıkartılabilir.

Tablo 7: Cinsiyet Değişkeni İçin Grup İstatistiği Ve "Bağımsız Örneklem T Test" Sonuçları

\begin{tabular}{|c|c|c|c|c|c|}
\hline Faktörler & Cinsiyetiniz & $\mathbf{N}$ & Ortalama & $\begin{array}{l}\text { Levene Testi } \\
\text { P Değeri }\end{array}$ & $\begin{array}{l}\text { T Testi } \\
\text { P Değeri }\end{array}$ \\
\hline \multirow[t]{2}{*}{ Tüketici sinizmi } & Kadın & 184 & 3,5082 & 124 & ,000 \\
\hline & Erkek & 292 & 3,7568 & & 000 \\
\hline \multirow[t]{2}{*}{ Kaynağın uzmanlığı } & Kadın & 184 & 3,0565 & ,678 & 247 \\
\hline & Erkek & 292 & 2,9644 & & 232 \\
\hline \multicolumn{2}{|c|}{ Tavsiyenin aldatılmayıKadın } & 184 & 3,2255 & ,662 & 145 \\
\hline azaltması & Erkek & 292 & 3,1438 & & 141 \\
\hline \multirow[t]{2}{*}{ Tavsiyeye güven } & Kadın & 184 & 3,3152 & ,680 & 313 \\
\hline & Erkek & 292 & 3,2511 & & 313 \\
\hline \multirow[t]{2}{*}{ Tavsiyenin etkisi } & Kadın & 184 & 3,3207 & ,551 & 116 \\
\hline & Erkek & 292 & 3,1952 & & 115 \\
\hline \multicolumn{2}{|c|}{ Tavsiyenin şüpheyeKadın } & 184 & 3,2478 & ,001 & 006 \\
\hline düşürücülüğg̈ü & Erkek & 292 & 3,0521 & & ,004 \\
\hline \multirow{2}{*}{$\begin{array}{l}\text { Memnuniyetsizlik } \\
\text { ve onaylamama }\end{array}$} & Kadın & 184 & 3,4752 & 200 & , 000 \\
\hline & Erkek & 292 & 3,2094 & & 000 \\
\hline
\end{tabular}

Medeni hal değişkeninde ise; Levene Testi P Değeri “kaynağın uzmanlığı" ( $\mathrm{p}=0,001)$, "tavsiyenin etkisi" $(\mathrm{P}=0,001)$ ve "tavsiyenin şüpheye düşürücülüğ ̈̈" $(p=0,049)$ faktörlerinde $p<0,05$ olduğundan bu faktörlerde varyansların eşit dağılmadığı varsayılmakta ve H0 hipotezi reddedilebilmektedir. T Testi P Değeri sonuçlarındaysa; "kaynağın uzmanlığı" $(p=0,004)$, "tavsiyenin aldatılmayı azaltması" ( $p=0,000)$, "tavsiyeye güven" $(p=0,000)$ ve "memnuniyetsizlik ve onaylamama" $(p=0,005)$ faktörlerinde $p>0,05$ 
olup bu faktörler için H0 hipotezi reddedilebilmektedir. Bir başka anlatımla bahsi geçen faktörlerde gruplar arasında (evli ve bekar) anlamlı bir farklılık vardır. "Kaynağın uzmanlığı" faktöründe evli=3,1730 ve bekar=2,9220; "tavsiyenin aldatılmayı azaltması" faktöründe evli=3,4426 ve bekar=3,0549; "tavsiyeye güven" faktöründe evli=3,5090 ve bekar=3,1707; "memnuniyetsizlik ve onaylamama" faktöründe evli=3,4440 ve bekar=3,2526'dir. Görüldüğü gibi gruplar arasında anlamlı bir farklılık olan faktörlerin tümünde evlilerin ortalaması bekarlardan daha yüksektir. Buradan yola çıkarak ağızdan ağıza pazarlama faaliyetleri karşısında evlilerin bekarlardan daha sinik bir tutum sergiledikleri sonucuna varılabilmektedir.

\section{Tek Yönlï Varyans Analizi}

Demografik değişkenlerden eğitim, meslek, gelir ve yaş değişkenleri içerisindeki grup sayısı üçten fazla olduğu için bahsi geçen değişkenlere ait gruplar arasında anlamlı bir farklılık olup olmadığını bulabilmek amacıyla "tek yönlü varyans analizi" gerçekleştirilmiştir. Bu analize ilişkin hipotezler şöyledir;

- Ho: $\mu 1=\mu 2=\mu 3=\mu 4=\mu 5$ (Faktörlere yönelik tüketici tutumlarında, değişkenlere ait gruplar arasında anlamlı bir farklılık bulunmamaktadır)

- Hı: $\mu j^{\prime} l e r d e n$ en az biri diğerlerinden farklıdır (Faktörlere yönelik tüketici tutumlarında, değişkenlere ait grupların en az biri ile diğerleri arasında anlamlı bir farklılık bulunmaktadır)

Eğitim değişkenine ait grupların araştırmaya ait ölçeklerden oluşturulan faktörler konusunda düşüncelerinde anlamlı bir farklılık olup olmadığı noktasında sınamanın $p$ değerlerine bakıldığında sadece "tavsiyenin şüpheye düşürücülüğ̈̈" faktöründe $p=0,053$ olup bu faktörde $p>0,05$ olduğundan H0 hipotezi reddedilememektedir. Bir başka anlatımla "tavsiyenin şüpheye düşürücülüğ̈̈̈" faktörü için gruplar arasında anlamlı bir farklılık bulunmamaktadır. Fakat diğer altı faktörün tümünde gruplar arasında anlamlı bir farklılık vardır ve bundan dolayı da kalan altı faktör için H0 hipotezi reddedilebilmektedir. "Tüketici sinizmi" ölçeğinde bu anlamlı farklılık ilkokul ile üniversite arasında olup üniversitenin ortalaması daha yüksektir. "Kaynağın uzmanlığı" faktöründe ilkokul ile üni- 
versite arasında olup yine üniversitenin ortalaması daha yüksektir. "Tavsiyenin aldatılmayı azaltıcı etkisi" faktöründe ilkokul ile üniversite ve lisansüstü arasındadır ve ilkokulun ortalaması daha düşüktür. "Tavsiyeye güven" ve "tavsiyenin etkisi" faktörlerinde de ilkokul ile lise, üniversite ve lisansüstü arasında olup yine ilkokulun ortalaması düşüktür. "Memnuniyetsizlik ve onaylamama" faktöründeyse anlamlı farklılık bu kez lise ile lisansüstü arasında olup lisenin ortalaması daha düşüktür. Verilen bu sonuçlara göre genelde ilkokul mezunlarının faktörlere yönelik ortalamasının daha düşük olduğu görülmektedir buna göre ilkokul mezunlarının faktörlere yönelik bakış açısı diğer eğitim seviyesine sahip katılımcılardan daha azdır denebilmekte, onları da lise mezunları takip etmektedir. Kat1lımcılar üzerinden değerlendirildiğinde, eğitim seviyesi arttıkça tüketicilerin faktörlere yönelik ortalamaları da (sinik tutum ortalaması ve ağızdan ağıza pazarlamanın sinik davranışları arttırma etkisi) artmaktadır. Zaten he ne kadar "tavsiyenin şüpheye düşürücülüğ̈̈̈" faktöründe gruplar arasında anlamlı bir farklılık olmadığı sonucu çıksa da Post Hoc sınamasında yine ilkokul ve lise ortalamasının ortalama farklılıkları sütununda (mean difference sütunu) daha düşük olduğu görülmektedir. Böylece eğitim seviyesi arttıkça katılımcılar daha fazla sinik tutum içerisinde olmakta ve ağızdan ağıza pazarlama eylemlerinden etkilenerek sinik davranışlar gösterebilmektedir denilebilir. Aşağıdaki Tablo 8'de eğitim değişkenine ait tek yönlü varyans analizi sonuçları verilmiştir.

Gelir değişkenine açısından tüm faktörlerde gruplar arasında anlamlı bir farklılık olduğu sonucu ortaya çıkmıştır. Sınamada "tavsiyenin şüpheye düşürücülüğ̈̈" faktöründe $\mathrm{p}=0,003$, "memnuniyetsizlik ve onaylamama" faktöründe $p=0,036$, diğer beş faktörde ise $p=0,000$ olup tümünde $\mathrm{p}<0,05$ 'dir. Böylece gelir değişkeni için $\mathrm{H} 0$ hipotezi reddedilebilmektedir. Post Hoc sınamasında anlamlı farklılığın "tüketici sinizmi" faktöründe €2020'den az ile €8001 ve üstü hariç diğer tüm değişkenler arasında olduğu görülmüştür. €2020'den az ile €8001 ve üstü grupları arasında anlamlı bir farklılık yoktur; fakat diğer gruplarla arasında anlamlı bir farkl1lık bulunmaktadır. "Kaynağın uzmanlığı" faktöründe €2020'den az ile €2021-€4000 arasında, €2021-€4000 ile €4001-€6000 arasında olduğu görülmüştür. "Tavsiyenin aldatılmayı azaltma" faktöründe €2020'den az ile €4001-€6000 hariç düğer tüm faktörler arasında, €4001-£6000 ile €8001 ve üstü arasında olduğu görülmektedir. "Tavsiyeye güven" faktöründe 
€2020 ile €2020'den az arasında, “tavsiyenin etkisi" faktöründe €6001-8000 ile $€ 8001$ ve üstü arasında, "tavsiyenin şüpheye düşürücülüğü" ve "memnuniyetsizlik ve onaylamama" faktörlerinde ‡6001-8000 ile £2020 arasında olduğu görülmektedir. Gelir değişkeni için eğitim değişkeninde olduğu gibi bir yorumlama yapmak güçtür. Eğitim değişkeni için ortalamalara bakıldığında eğitim arttıkça ölçeklerin ortalaması da artmaktaydı; fakat gelir değişkeninde böyle bir sıralama söz konuş değildir. Her faktöre göre gelirdeki grupların bakış açısı değişiklik göstermektedir.

Tablo 8: Eğitim Değişkenine Ait Tek Yönlü Varyans Analizi Sonuçlan

\begin{tabular}{|c|c|c|c|}
\hline Faktörler & & $\mathbf{F}$ & $\mathbf{P}$ \\
\hline Tüketici sinizmi & $\begin{array}{l}\text { Gruplar Arasında } \\
\text { Gruplar İçerisinde } \\
\text { Toplam }\end{array}$ & 5,697 & ,001 \\
\hline Kaynağın uzmanlığı & $\begin{array}{l}\text { Gruplar Arasında } \\
\text { Gruplar İçerisinde } \\
\text { Toplam }\end{array}$ & 4,631 & ,003 \\
\hline Tavsiyenin aldatılmayı azaltması & $\begin{array}{l}\text { Gruplar Arasında } \\
\text { Gruplar İçerisinde } \\
\text { Toplam }\end{array}$ & 5,145 & ,002 \\
\hline Tavsiyeye güven & $\begin{array}{l}\text { Gruplar Arasında } \\
\text { Gruplar İçerisinde } \\
\text { Toplam }\end{array}$ & 14,053 & 000 \\
\hline Tavsiyenin etkisi & $\begin{array}{l}\text { Gruplar Arasında } \\
\text { Gruplar İçerisinde } \\
\text { Toplam }\end{array}$ & 6,393 & 000 \\
\hline Tavsiyenin şüpheye düşürücülüğü & $\begin{array}{l}\text { Gruplar Arasında } \\
\text { Gruplar İçerisinde } \\
\text { Toplam }\end{array}$ & 2,578 & , 053 \\
\hline Memnuniyetsizlik ve onaylamama & $\begin{array}{l}\text { Gruplar Arasında } \\
\text { Gruplar İçerisinde } \\
\text { Toplam }\end{array}$ & 3,649 & ,013 \\
\hline
\end{tabular}

Meslek değişkenine ait gruplarda da yine tüm faktörlerde anlamlı bir farklılık olduğu sonucu çımıştır. Tüm faktörlerde $p<0,05$ olup H0 hipotezi reddedilebilmektedir. Post Hoc sinamasinda genel olarak bakıld1ğında bu anlamlı farklılık yönetici, uzmanlık gerektiren işler (avukat, dok- 
tor, mühendis vs.) ve işsizler arasında olduğu görülmektedir. Bu grupların ortalamaları her faktörde değişiklik göstermekte olup kimisinde yönetici, kimisinde uzman, kimisinde de işsiz grubunun ortalaması daha yüksektir. Bundan dolayı da eğitim değişkeni açısından da sıralı bir ilişki (ordinal) yapılamamaktadır.

Yaş değişkeninde "kaynağın uzmanlığı" faktörü için $p=0,351$ olup bu değişken açısından gruplar arasında anlamlı bir farklılık bulunmakta olup H0 hipotezi reddedilememektedir. Diğer faktörlerin tümünde ise; $p<0,05$ olup H0 hipotezi reddedilebilmektedir. Bir başka anlatımla diğer altı faktörün tümünde yaş değişkenine ait gruplar arasında anlamlı bir farklılık bulunmaktadır. "Tüketici sinizmi" faktöründe ortalamalar yaş arttıkça artmaktadır. Dolayısıyla "tüketici sinizmi" faktörü için sıralı bir ilişki (ordinal) söz konusu olmaktadır. Yaş arttıkça tüketicilerin/katılımcıların sinik tutum ve davranışlarının derecesi de artmaktadır. Aynı durum "kaynağın uzmanlığı" ve "tavsiyenin aldatılmayı azaltması" faktörlerinde de söz konusudur. Bu faktörlerde yaş arttıkça ortalamalar artmaktadır. Fakat "tavsiyeye güven" faktöründe tersine yaş azaldıkça ortalamalar artmaktadır. Buradan yola çıkarak yaş azaldıkça katılımcılar tavsiyeleri daha fazla dikkate almaktadırlar sonucu çıkartılabilmektedir ve "tavsiyeye güven" faktörü için de bir sıralı ilişki mevcuttur. Ancak diğer üç faktörde böyle bir sıralı ilişki söz konusu değildir. Yaş değişkeni için yapılan Post Hoc sınamasında en dikkat çeken anlamlı farklılıklar; "tüketici sinizmi", "tavsiyeye güven" (17 yaş ve altı grubunun ortalaması küçük) ve "tavsiyenin aldatılmayı azaltması" faktöründe 17 yaş ve altı ile 45-54 yaş arasındadır (17 yaş ve altı grubunun ortalaması büyük). "Tavsiyenin etkisi" faktöründe 25-34 (ortalaması daha az) ile 45-54 yaş arasında, "tavsiyenin şüpheye düşürücülüğ̈̈" faktöründe 17 yaş ve altı (ortalaması daha az) ile 18-24 yaş arasında, "memnuniyetsizlik ve onaylamama" faktöründe 45-54 (ortalaması daha az) ile 35-44 yaş aralıkları arasınadır.

\section{Çoklu Regresyon analizi}

"Ağızdan ağıza pazarlama" ölçeğine ait faktörlerin "tüketici sinizmi" faktörü üzerindeki etkiyi belirleyebilmek amaciyla "çoklu regresyon" sınaması gerçekleştirilmiştir. Dolayısıyla regresyon modelinde "ağızdan ağıza pazarlama" ölçeğine ait altı faktör bağımsız değişken, "tüketici sinizmi" 
ölçeğine ait faktör ise bağımlı değişen olarak belirlenmiş ve buna göre modeller kurulmuştur. Kurulan modellerde bağımsız değişkendeki nispi değişimin bağımlı değişkende nasıl bir değişime yol açtığı görülmektedir. Regresyon analizinde modelin açıklama gücü ve etki katsayısına yönelik hipotezler aşağıda sıralanmıştır.

Modelin açıklama gücüne (belirlilik katsayısı) yönelik hipotezler;

- $\mathrm{H}_{0}: \mathrm{R}^{2}=0$

- $\mathrm{H}_{1}: \mathrm{R}^{2}>0$

Etki katsayısına (regresyon katsayısı) yönelik hipotezler;

- $\mathrm{H}_{0}: \beta=0$

- $\mathrm{H}_{1}: \beta \neq 0$

İstatistik bilimine göre yukarıdaki gibi belirtilen etki katsayısına yönelik hipotezleri, kurulan modellere göre açıklamak gerekirse, çoklu regresyon analizine ait hipotezler aşağıdaki gibidir ve Şekil 1'de gösterilmektedir;

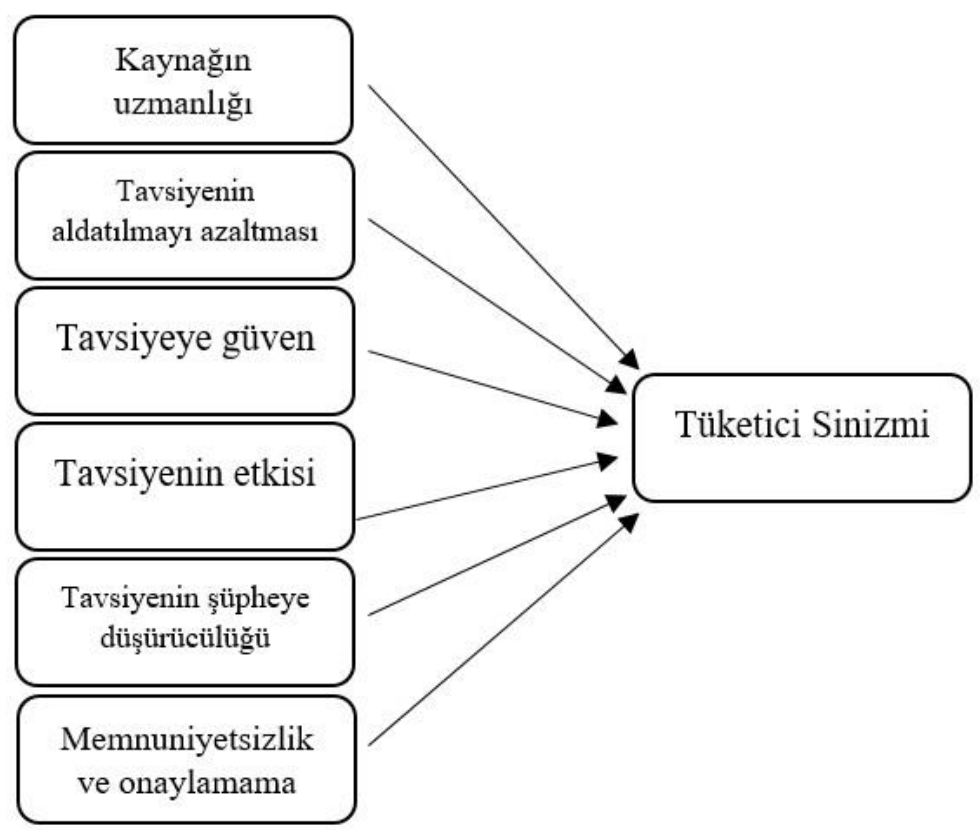

Şekil 1: Çoklu Regresyon Analizi Hipotezleri

- H1: Kaynağın uzmanlığı bağımsız değişkeninin tüketici sinizmi bağımlı değişkeni üzerinde olumlu bir etkisi vardır. 
- H2: Tavsiyenin aldatılmayı azaltması bağımsız değişkeninin tüketici sinizmi bağımlı değişkeni üzerinde olumlu bir etkisi vardır.

- H3: Tavsiyeye güven bağımsız değişkeninin tüketici sinizmi bağımlı değişkeni üzerinde olumlu bir etkisi vardır.

- H4: Tavsiyenin etkisi bağımsız değişkeninin tüketici sinizmi bağımlı değişkeni üzerinde olumlu bir etkisi vardır.

- H5: Tavsiyenin şüpheye düşürücülüğü bağımsız değişkeninin tüketici sinizmi bağımlı değişkeni üzerinde olumlu bir etkisi vardır.

- H6: Memnuniyetsizlik ve onaylamama bağımsız değişkeninin tüketici sinizmi bağımlı değişkeni üzerinde olumlu bir etkisi vardır.

Tablo 9 incelendiğinde çoklu regresyon analizi için modelin açıklama gücünde (birden fazla bağımsız değişken olduğu için düzeltilmiş $\mathrm{R}^{2}$ dikkate alınmıştır) $R^{2}=0,386$ ve $p=0,000$ olduğu görülmektedir. Bu sonuçlar neticesinde modelin açıklama gücü için $\mathrm{H} 0$ hipotezi reddedilebilmektedir. Modelin açıklama gücü; bağımlı değişkendeki toplam değişimin yüzde kaçının bağımsız değişken tarafından açıklandığını gösteren istatistiki bir ölçüttür. Çoklu regresyon analizinde de bu değer 0,386 olduğu için sınamaya göre "tüketici sinizmi" üzerindeki toplam değişimin \%38,6's1 "ağ1Zdan ağıza pazarlama" ile açılanabilmekteyken; kalan \%61,4'ü diğer değişkenlerce açıklanabilmektedir. $R^{2}$ değerinin $1^{\prime}$ e yakın olması modelin açıklama gücünün yüksek, tersine 0 'a yakın olması modelin açıklama gücünün düşük olduğu anlamına gelmektedir. Burada $R^{2}=0,386$ olduğu için modelin açıklama gücünün yüksek olmadığı söylenebilir. Ancak unutulmamalıdır ki çoklu regresyon analizinde bağımsız değişken sayısı fazla olduğundan $\mathrm{R}^{2}$ (özellikle de düzeltilmiş $\mathrm{R}^{2}$ ) genelde düşük çıkmaktadır.

Tablo 9'da kurulan altı modelin $\beta$ katsayılarına ve $\mathrm{p}$ değerlerine bakıldığında yine tüm modeller için bağımsız değişkenlerin bağımlı değişken üzerinde etkisi olduğu ve $\mathrm{p}=0,000$ olduğu görülmektedir. Elde edilen bu sonuçlara göre regresyon katsayısı için $\mathrm{H} 0$ hipotezi reddedilebilmektedir ve tüm bağımsız değişkenlerin bağımlı değişken üzerinde etkisi olduğu ifade edilebilmektedir. Tablo incelendiğinde "tüketici sinizmi" faktörü üzerinde en fazla etkiye "memnuniyetsizlik ve onaylamama" $(\beta=0,327)$ ve en az etkiye "kaynağın uzmanlığı" $(\beta=0,196)$ faktörleri sahiptir. $\beta$ değerlerine göre diğer her şey sabitken "memnuniyetsizlik ve onaylamama" faktöründeki 1 birimlik değişiklik "tüketici sinizmi" faktörü üzerinde 
0,327 birimlik bir değişikliğe yol açmaktadır. Regresyon analizinin $\beta$ değerlerine göre "ağızdan ağıza pazarlama" ölçeğine ait faktörlerin "tüketici sinizmi" faktörü üzerindeki etki düzeyinin çok da yüksek olmadığ 1 yorumu yapılabilmektedir; fakat buna rağmen yine de bir etkiye sahip olduğundan yokluk hipotezi olan H0 hipotezi reddedilebilmekte ve bağımsız değişkenlerin bağımlı değişken üzerinde etkisi vardır denilebilmektedir.

Tablo 9: Çoklu Regresyon Analizi Sonuçları

\begin{tabular}{|c|c|c|c|c|c|c|}
\hline Model & $\begin{array}{l}\text { Bağıımsız } \\
\text { Değişken }\end{array}$ & $\begin{array}{l}\text { Bağımlı } \\
\text { Değişken }\end{array}$ & $\mathbf{R}^{2}$ & $\begin{array}{l}\text { P Değeri } \\
\left(\mathbf{R}^{2)}\right.\end{array}$ & $\beta$ & $\begin{array}{l}\text { P Değeri } \\
(\beta)\end{array}$ \\
\hline 1 & $\begin{array}{l}\text { Kaynağın } \\
\text { uzmanlığ1 }\end{array}$ & $\begin{array}{l}\text { Tüketici } \\
\text { Sinizmi }\end{array}$ & 386 & ,000 & 196, & 000 \\
\hline 2 & $\begin{array}{l}\text { Tavsiyenin } \\
\text { aldatılmayı } \\
\text { azaltması }\end{array}$ & $\begin{array}{l}\text { Tüketici } \\
\text { Sinizmi }\end{array}$ & 386 & 000 & 294 & ,000 \\
\hline 3 & $\begin{array}{l}\text { Tavsiyeye } \\
\text { güven }\end{array}$ & $\begin{array}{l}\text { Tüketici } \\
\text { Sinizmi }\end{array}$ & 386 & 000 & 307 & 000 \\
\hline 4 & $\begin{array}{l}\text { Tavsiyenin } \\
\text { etkisi }\end{array}$ & $\begin{array}{l}\text { Tüketici } \\
\text { Sinizmi }\end{array}$ & 386 & ,000 & 314 & ,000 \\
\hline 5 & $\begin{array}{l}\text { Tavsiyenin } \\
\text { şüpheye } \\
\text { düşürücülüğü }\end{array}$ & $\begin{array}{l}\text { Tüketici } \\
\text { Sinizmi }\end{array}$ & 386 & 000 & 234 & 000 \\
\hline 6 & $\begin{array}{l}\text { Memnuniyetsizlik } \\
\text { ve onaylamama }\end{array}$ & $\begin{array}{l}\text { Tüketici } \\
\text { Sinizmi }\end{array}$ & 386 & ,000 & 327 & ,000 \\
\hline
\end{tabular}

\section{Korelasyon Analizi}

“Ağızdan ağıza pazarlama" ölçeğine ait faktörler arasındaki ilişkiyi görebilmek maksadıyla korelasyon analizi gerçekleştirilmiştir. Regresyon analizinde bağımsız değişkenler olan "ağızdan ağıza pazarlama" ölçeğine faktörlerinin "tüketici sinizmi" ölçeği faktörü üzerindeki etkisi sınanmıştı. Burada da ağızdan ağıza pazarlama" ölçeği faktörlerinin birbirleri ile ilişkisi gösterilmeye çalışılacaktır. Sınamada Pearson korelasyon katsayısı dikkate alınmıştır ve sınamanın hipotezler şunlardır;

- Ho: Değişkenler arasında ilişki yoktur.

- H1: Değişkenler arasında ilişki vardır.

Aşağıdaki Tablo 10'a göz atıldığında tüm faktörler arasındaki ilişkilerde $\mathrm{p}=0,000$ 'dır. Çıkan $\mathrm{p}$ değerlerine göre tüm faktörler arasında bir ilişki 
mevcuttur. İlişkilerin katsayı değerine bakıldığında "kaynağın uzmanlığı" faktörü ile "tavsiyenin aldatılmayı azaltması" faktörü arasındaki ilişkide $r=0,536$ olup iki faktör arasında pozitif doğrusal yönde ve orta şiddette ilişki bulunmaktadır. "Tavsiyenin aldatılmayı azaltması" faktörü ile "tavsiyenin etkisi" faktörleri arasındaki ilişkide $\mathrm{r}=0,519$ olup yine pozitif doğrusal yönde ve orta şiddette ilişki vardır. "Tavsiyeye güven" ile "tavsiyenin etkisi" faktörleri arasındaki ilişkinin $\mathrm{r}=0,597$ ' dir ve burada da pozitif doğrusal yönde ve orta şiddette ilişki söz konusudur. Tabloda görülmektedir ki, "tavsiyenin etkisi" faktörü ile diğer tüm faktörler arasındaki ilişki düzeyi diğer ilişki modellerinden daha yüksektir.

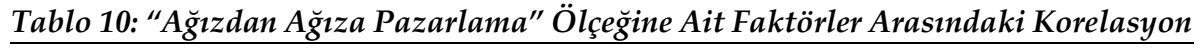

\begin{tabular}{|c|c|c|c|c|c|c|c|}
\hline & & $\begin{array}{l}\text { Kaynağın } \\
\text { uzman- } \\
\text { liğ1 }\end{array}$ & $\begin{array}{l}\text { Tavsiyenin } \\
\text { aldatılmayı } \\
\text { azaltması }\end{array}$ & $\begin{array}{l}\text { Tavsiyeye } \\
\text { güven }\end{array}$ & $\begin{array}{l}\text { Tavsiye- } \\
\text { nin } \\
\text { etkisi }\end{array}$ & $\begin{array}{l}\text { Tavsiyenin } \\
\text { şüpheye } \\
\text { düşürücü- } \\
\text { lüğ̈u }\end{array}$ & $\begin{array}{l}\text { Memnuniyet- } \\
\text { sizlik } \\
\text { ve } \\
\text { onaylamama }\end{array}$ \\
\hline \multirow{3}{*}{$\begin{array}{l}\text { Kaynağın } \\
\text { uzmanlığ1 }\end{array}$} & $\mathrm{r}$ & 1 &, $536^{* *}$ &, $383^{* *}$ &, $447^{* *}$ &, $182^{* *}$ & , $185^{* *}$ \\
\hline & $\underline{p}$ & & ,000 & , 000 & ,000 & , 000 & ,000 \\
\hline & $\mathrm{n}$ & 476 & 476 & 476 & 476 & 476 & 476 \\
\hline \multirow{3}{*}{$\begin{array}{l}\text { Tavsiyenin } \\
\text { aldatılmayı } \\
\text { azaltması }\end{array}$} & $\mathrm{r}$ &, $536^{* *}$ & 1 & $366^{* *}$ &, $519^{* * *}$ & ,242** & $383^{* * *}$ \\
\hline & p & ,000 & & ,000 & ,000 & , 000 & ,000 \\
\hline & $\mathrm{n}$ & 476 & 476 & 476 & 476 & 476 & 476 \\
\hline \multirow{3}{*}{$\begin{array}{l}\text { Tavsiyeye } \\
\text { güven }\end{array}$} & $\mathrm{r}$ &, $383^{* *}$ & , 366 & 1 & ,597** & $472^{* *}$ & ,644 \\
\hline & $p$ & ,000 & , 000 & & ,000 & ,000 & ,000 \\
\hline & $\mathrm{n}$ & 476 & 476 & 476 & 476 & 476 & 476 \\
\hline \multirow{3}{*}{$\begin{array}{l}\text { Tavsiyenin } \\
\text { etkisi }\end{array}$} & $\mathrm{r}$ &, $447^{* *}$ & ,519** &, $597^{* *}$ & 1 & $404^{* *}$ &, $553^{* *}$ \\
\hline & $p$ & ,000 & ,000 & , 000 & & ,000 & ,000 \\
\hline & $\mathrm{n}$ & 476 & 476 & 476 & 476 & 476 & 476 \\
\hline \multirow{3}{*}{$\begin{array}{l}\text { Tavsiyenin } \\
\text { Şüpheye } \\
\text { düşürücülüğü } \\
\end{array}$} & $\mathrm{r}$ & $182^{* *}$ & ,242 & $472^{* *}$ & $404^{* * *}$ & 1 & $465^{* *}$ \\
\hline & p & ,000 & ,000 & ,000 & ,000 & & ,000 \\
\hline & $\mathrm{n}$ & 476 & 476 & 476 & 476 & 476 & 476 \\
\hline \multirow{3}{*}{$\begin{array}{l}\text { Memnuniyet- } \\
\text { sizlik } \\
\text { ve } \\
\text { onaylamama }\end{array}$} & $r$ & $185^{* *}$ & ,383** & ,644 & ,553 & $465^{* *}$ & 1 \\
\hline & $\mathrm{p}$ & ,000 & ,000 & ,000 & ,000 & ,000 & \\
\hline & $\mathrm{n}$ & 476 & 476 & 476 & 476 & 476 & 476 \\
\hline
\end{tabular}


"Tavsiyenin etkisi" faktörünün en az ilişkide olduğu faktör r=0,404 ile "tavsiyenin şüpheye düşürücülüğü" faktörü arasındadır ve r değeri 0,40,6 arasında olduğu için yine pozitif doğrusal yönde ve orta şiddettedir. "tavsiyenin şüpheye düşürücülüğ̈̈" ile "tavsiyeye güven" faktörleri arasındaki ilişkide $r=, 472$ 'dir. Bu iki faktör arasındaki ilişkinin de şiddeti orta düzeydedir. "Memnuniyetsizlik ve onaylamama" faktörü ile "tavsiyeye güven" faktörleri arasındaki ilişkide r=0,644 olup r=0.6-0.8 arası olması sebebiyle de faktörler arasında pozitif doğrusal yönde ve yüksek şiddette ilişki vardır. Tabloya göre en az ilişki r=0,182 ve $r=, 185$ ile "kaynağın uzmanlığı" faktörü ile "tavsiyenin şüpheye düşürücülüğü" ve "memnuniyetsizlik ve onaylamama" faktörleri arasında olup faktörler arasındaki ilişkinin şiddeti çok zayıftır. Faktörler arasındaki r değerlerine göre; herhangi bir faktörlerdeki 1 birimlik değişiklik ilişkili olduğu diğer faktör üzerinde aynı yönde $r$ değeri kadar değişikliğe yol açmaktadır. Örneğin "tavsiyeye güven" faktöründeki 1 birimlik değişiklik "memnuniyetsizlik ve onaylamama" faktörü üzerinde 0,644 birimlik bir değişikliğe sebebiyet vermektedir. Tüm bu veriler neticesinde $\mathrm{H0}$ hipotezi reddedilebilmekte ve faktörlerin hepsinin arasında şiddeti çok zayıf da olsa, yüksek de olsa bir ilişki mevcuttur yorumu yapılabilmektedir.

\section{Bulguların Dĕgerlendirilmesi}

Araştırmadan elde edilen bulguları özetleyecek olursak;

$\checkmark$ Katılımcıların "tüketici sinizmi” ölçeği ortalaması 3,6607'dır. Bu ortalamaya göre katılımcılar az da olsa (4 ile kodlanan "katılıyorum" seçeneğinin altında olduğu için) sinik tutum sergilemektedir,

$\checkmark$ "Tüketici sinizmi" ölçeği içerisindeki en yüksek ortalama 4,09 ile "Eğer paramın karşılığını almadığımı düşünüyorsam, markanın bana söylediklerine inanmam" önermesidir. Buna göre katılımcilar ödedikleri bedel ile kullanımda tutarsızlık görürlerse, markanın vaatlerine inanmamaktadır,

$\checkmark$ "Tüketici sinizmi" ölçeği içerisindeki en düşük ortalama 3,13 ile "Markalar ürünlerini satın aldığımın sonrasında ne olacağını umursamamaktadırlar" önermesidir. Buna göre katılımcılar markaların umursamaz davranışlar içerisinde olduğu düşüncesine çok az bir farkla katılmaktadırlar, 
$\checkmark$ "Ağızdan ağıza pazarlama" ölçeği faktörleri içerisinde en düşük ortalamaya 3,000 ile "kaynağın uzmanlığı" faktörü sahiptir. Buna göre katılımcılar kaynağın uzmanlığı konusunda yansız bir fikre sahiptir,

$\checkmark$ "Ağızdan ağıza pazarlama" ölçeği faktörleri içerisinde en yüksek ortalamaya 3,3121 ortalama ile "memnuniyetsizlik ve onaylamama" faktörü sahiptir. Ortalaması en yüksek olan faktörün ortalamasının bile 3,3121 olduğu göz önüne alınırsa, katılımcların "ağızdan ağıza pazarlama" eylemlerinden çok az etkilendikleri ve çok az sinik tutum ve davranışlar sergiledikleri söylenebilir,

$\checkmark$ "Bağımsız örneklem $\mathrm{t}$ testi" sonuçlarına göre erkekler kadınlardan daha sinik tutumlar sergilemektedir; fakat buna rağmen kadınlar ağızdan ağıza pazarlama eylemlerinden daha fazla etkilenerek sinik tutumlar sergilemektedir. Yani erkekler ağızdan ağıza pazarlama eylemi olmadan önce daha fazla sinik tutma sahiptir; ancak ağızdan ağıza pazarlama çalışması yapıldığında kadınlar daha fazla bundan etkilenerek sinik tutumlar göstermektedir,

$\checkmark$ "Bağımsız örneklem $t$ testi" sonuçlarına göre ağızdan ağıza pazarlama faaliyetleri karşısında evliler bekarlardan daha sinik bir tutum sergilemektedirler,

$\checkmark$ "Bağımsız örneklem $t$ testi" sonuçlarında "tüketici sinizmi" faktöründe medeni hal değişkeni açısından gruplar arasında anlamlı bir farklılık bulunmamaktadır,

$\checkmark$ "Tek yönlü varyans analizi" sonuçlarına göre eğitim seviyesi arttıkça tüketicilerin sinik tutum ve davranış dereceleri de artmakta ve ağızdan ağıza pazarlama eylemleri neticesinde sinik tutum ve davranış seviyeleri de artmaktadır. Araştırmada genelde ilkokul mezunlarının faktörlere yönelik ortalamasının daha düşük olduğu görülmekte ve onları da lise mezunları takip etmektedir. Katılımcılar üzerinden değerlendirildiğinde, eğitim seviyesi arttıkça tüketicilerin faktörlere yönelik ortalamaları da artmaktadır,

$\checkmark$ "Tek yönlü varyans analizi" sonuçlarına göre ("tüketici sinizmi" ölçeği ortalamalarına göre) yaş arttıkça tüketiciler daha sinik tutum ve davranışlar göstermektedir,

$\checkmark$ "Tek yönlü varyans analizi" sonuçlarına göre "kaynağın uzmanlığı" ve "tavsiyenin aldatılmayı azaltması" faktörleri için tüketiciler yaş artıkça bu iki faktörü daha fazla dikkate almaktadırlar, 
$\checkmark$ "Tek yönlü varyans analizi" sonuçlarına göre "tavsiyeye güven" faktöründe yaş azaldıkça katılımcılar tavsiyeleri daha fazla dikkate almaktadırlar,

$\checkmark$ "Çoklu regresyon analizi" sonuçlarına göre "ağızdan ağıza pazarlama" ölçeği faktörlerinin "tüketici sinizmi" faktörü üzerinde az da olsa bir etkisi bulunmaktadır,

$\checkmark$ "A ğızdan ağıza pazarlama" ölçeğine ait faktörler arasında bir ilişki mevcuttur.

\section{Sonuç ve Öneriler}

Markalar yaptıkları pazarlama iletişimi faaliyetleri ile gerçek ve olası müşterileriyle temas kurmakta ve bu kurulan temas sonucunda tüketicilerin kendilerini tercih etmelerini sağlamaya çalışmaktadırlar. Markalar bunu sağlayabilmek için de tüketicilere çeşitli vaatler sunmaktadır. Tüketiciler sunulan bu taahhütleri değerlendirmekte ve buna göre bir karar vermektedir. Bu karar markanın satın alınıp alınmamasıdır. Tüketiciler eğer markanın sunduğu vaatler karşısında ikna olmuş ve satın alma işlemini gerçekleştirmiş ise bu kez markanın söyledikleri ile karşılaştıkları şeyin örtüşüp örtüşmediğini denetlemekte, çözümlemektedirler. Eğer markanın söyledikleri ile gerçekleşen arasında bir farklılık olmaz ise, bir başka deyişle örtüşürse tüketici markadan memnun olacak ve satın alma davranışını, marka ile kurduğu ilişkiyi sürdürecektir. Ancak tersi olursa, markanın söyledikleri ile gerçekleşen arasında bir farklılık ortaya çıkarsa tüketici tatmin olmayacak, müşteri memnuniyeti sağlanmayacaktır ve böyle bir durumda da tüketici marka ile olan ilişkisini kesecektir.

Tüketicilerle markalar arasında karşılıklı menfaate dayalı bir ilişki söz konusudur. Burada markanın menfaati kar, müşterinin menfaati ise doyumdur. Her iki tarafta bahsi geçen menfaatlere sahip olmaya devam ettiği sürece ilişki devam eder; fakat taraflardan biri bahsi geçen menfaate sahip olmazsa ilişki kesilir. Yani marka kar edebilir; ancak müşteri markadan memnun olmazsa müşteri markayla olan ilişkisini sonlandırır. Bu durum pazarlama kavramı içerisinde kısaca ilişkisel pazarlama olarak adlandırılmaktadır ve ilişkisel pazarlamada bahsi geçen kurgu uzun vadeli 
olmalıdır. Bunun içinde tarafların kendilerine düşen sorumlulukları yerine getirmesi gerekmekte, müşteri markanın kar elde etmesini, markada da müşterinin tatmin olmasını sağlayacaktır.

Tüketici açısından bakıldığında eğer müşteri memnun olmaz, markanın sundukları taahhütler ile gerçekleşen örtüşmezse bu kez müşteri markalarla ilgili şüphe etmeye, kaygı duymaya başlayacak, markanın kendisini aldattığını, söylenen ile karşılaşılanın uyuşmadığını düşünecek ve kısacası beklentilerin karşılanmamasından kaynaklı olarak markalarla ilgili kalite düzeyi konusunu konuşmaya, dillendirmeye başlayacaktır. Müşterinin bu tavrı bundan sonraki alışverişlerinde de yansıyacak, markalara karşı bir önyarg1, tedirginlik duyabilecektir. İşte müşterilerin markaların sundukları vaatleri yerine getirmemesinden kaynaklı olarak oluşan hayal kırıklığı, kaygı, şüphe, aldatılma korkusu, markaların hilekar oldukları hissiyatı gibi düşüncelere ve bunu davranış olarak göstermelerine pazarlama alanyazınında "tüketici sinizmi" kavramı denmektedir. Bu noktadan sonra tüketiciler markalardan hoşlanmama, beğenmeme, markalara güvenmeme ve onlara karşı olumsuz tutum ve davranışlar besleme gibi olumsuz duygulara ve düşüncülere sahip olmaktadır ve bunu satın alama davranışlarında da belli etmektedir. Markaların böyle bir durum karşısinda müşterilerin güvenini kazanmak gibi bir görevi bulunmaktadır.

Ağızdan ağıza pazarlama kavramı; bir tüketicinin başka tüketicilerle bir araya geldiği bir ortamda (kadınların yaptıkları günler olur, bir arkadaş ortamı, yemekli bir buluşma, yolda karşılaşma, eve misafirliğe gitme, sınıfta başlayan bir sohbet esnasında v.s.) bir marka ile ilgili olumlu ya da olumsuz söyledikleri şeyler ve bu söylenenlerle karşı tarafın marka hakkında olumlu ya da olumsuz bir kanaate vardığ 1 bir pazarlama iletişimi biçimidir. Markalar açısından doğal olarak ağızdan ağıza pazarlamada müşterinin yapması gereken eylem; marka hakkında güzel şeyler konuşması ve böylece markanın imajının güçlenmesi, satın alınma işleminin artmasıdır. Ancak tersi bir durum olduğunda, marka hakkında olumsuz şeyler konuşulduğunda dinleyen bundan ne derece etkilenmekte ve sinik tutum ve davranışlar sergilemektedir.

Eldeki çalışma ile öncelikle tüketicilerin sinik tutum ve davranışlar sergileyip sergilemediği ve siniklik derecesi anlaşılmaya çalışılmış ve sonrasında da tüketicilerin olumsuz ağızdan ağıza pazarlama davranışlarından ne derece etkilendiği anlaşılmaya çalışılmıştır. Ancak unutulmamalıdır ki 
yorumlamalar sadece araştırmanın katılımclarının verdikleri yanıtlar neticesinde elde edilen bulgulardan yola çıkılarak yorumlanmıştır. Dolayısıyla araştırma sonuçlarını sadece katılımcılar üzerinden sınırlamak ve tüm tüketiciler için genellememek gerektiği de unutulmamalıdır. Bundan dolayı da araştırma yorumlanırken katılımcılar açısından irdelenmekte ve katılımclar üzerinden olumsuz ağızdan ağıza pazarlamanın tüketici sinizmi üzerindeki etkisi anlatılmaya çalışılmaktadır.

Yukarıdaki bulgulara göre araştırma ile ilgili bir genelleme yapılacak olursa, katılımcılar az da olsa sinik tutum ve davranışlara sahiptir ve yine az da olsa olumsuz "ağızdan ağıza pazarlama" eylemleri katılımcıların sinik tutumlar göstermesine yol açmaktadır. Bu sonuç hem faktörlerin ortalamasında hem de regresyon analizinde kendini göstermektedir. Her iki sınama sonuçlarına göre katılımcılar sinik tutum ve davranışların sergilenmesinde "ağızdan ağıza pazarlama" eylemlerinden az derecede etkilenmektedir yargısına varılabilmektedir. Böylece araştırmanın temel hipotezlerinde belirtilen alternatif hipotezlerin ikisi de (H1a ve $\mathrm{H} 1 \mathrm{~b})$ kabul edilebilmektedir. Ancak elde edilen bu sonuçların sadece 476 katılımcının anketi yanıtlaması ile elde edilen bulgular olduğu unutulmamalıdır. Eldeki bu çalışmada; katılımcıların sinik tüketici davranışları gösterdikleri; fakat bu davranışların seviyesinin çok yüksek olmadığı 4 ile kodlanan "katılıyorum" seçeneğinden daha düşük çıtığı ve olumsuz ağızdan ağıza pazarlama faaliyetlerinin bu sinik tutum ve davranışların derecesini çok az arttırdığı, tetiklediği sonucu çıkmıştır. Ancak daha farklı ve daha fazla katılımcı ile yapılacak bir araştırmada daha farklı sonuçlar çıkabileceği unutulmamalıdır. Bundan dolayı da yorumlamalar sadece katılımcılar üzerinden yapılmış olup tüm tüketiciler için genelleştirilmemiştir. Misal olarak çalışmada, erkeklerin ve evlilerin daha sinik tutuma sahip oldukları; ancak kadınların bir sinizm baskısı ile karşılaştığında daha fazla etkilendiği sonucu çıkmıştır. Psikoloji alanında yapılan çalışmalarda, kadınların daha saf duygularla hareket ettiği ve erkeklerin ise daha ihtiyatlı davrandığı konusunda iddialar bulunmaktadır. Ayrıca kadınların tüketim, alışveriş noktasında erkeklerden daha hedonik davranışlar sergilediğine dair bulguların olduğu pek çok çalışma da mevcuttur. Bunlara dayanarak erkeklerin daha sinik tüketici davranışları sergilemesi araştırmanın sonucunun tutarlılık gösterdiğine dair bir sonuç olarak yorumlanabilmektedir. Evlilerin bekarlardan daha sinik tutuma sahip olmasını ise; bekar 
bir bireyin daha savruk ve düşüncesiz (sadece kendisini düşünerek) bir biçimde davranması; ancak evli bir kişinin sadece kendisini düşünerek değil; eşini, evlatlarını da düşünerek hareket etmesi ve bundan dolayı da daha temkinli yaklaşması şeklinde değerlendirilebilir. Tüketici davranışlarında bireyin satın alma davranışlarını etkileyen unsurlardan biri de ailedir. Bir karar verici vardır ve bir de bu kararı etkileyenler bulunmaktadır. Birey bir ev, otomobil alacağı zaman dahi eşini, çocuklarını dikkate alarak kararını vermektedir. Bundan dolayı evli bireylerin daha sinik tutumlar sergilemesi doğal bir sonuç gibi görünmektedir. Fakat bu durumun gerçekten de böyle olup olmadığı başka çalışmalarla da desteklenebilmelidir.

Çalışma; Amezcua ve Quintanilla'nın (2016) sinik tüketici tarafından yapılan ağızdan ağıza pazarlamanın markayı olumsuz etkilediği, Chylinski ve Chu'nun (2008) aldatılan tüketicinin sinik ağızdan ağıza pazarlama eylemleri içerisinde olarak markayı cezalandırdığı, Helm'in (2004) sinik tüketicilerin marka ile ilgili olumsuz sözler yaydığı ve çevresindekileri etkilediği şeklinde bulgulara rastladıkları araştırmalarla benzerlikler göstermektedir. Çalışmanın; tüketici sinizmi konusunda ülkemiz olan Türkiye'de çok az çalışma olduğu için alanyazına bir katkısı olacağı, pazarlama akademisyen ve uzmanlarına, markalara bir fikir vereceği bir gerçektir. Çünkü tüketicinin, markanın sunduğu vaatlerle gerçekleşen arasında bir uyumsuzluk olduğunda yüz yüze iletişimin yanı sıra sosyal medya gibi güçlü bir kanal ile (ve hatta daha çok insana ulaşarak) markanın aldatıcı ve pazarlama iletişimi çalışmasında söylediklerinin yalan olduğunu çevreye yaydığı bir olgu ile karşı karşıyayız. Tüketici artık markanın söyledikleri yalanlarla daha fazla savaşmakta (çünkü artık savaşabileceği mecra ve bu mecralarla ulaşabileceği kişi sayısı daha fazla olmakta) ve bu konuda gerçek ve sanal ortamda örgütlenerek markayı protesto edebilmektedir. Bu olumsuz ağızdan ağıza pazarlama durumu tüketici davranışlarını etkileyebilmektedir. Çünkü ağızdan ağıza pazarlamanın diğer pazarlama iletişimi faaliyetlerinden daha ikna edici bir araç olduğuna dair pek çok araştırma mevcuttur. Bundan dolayı da markaların yapması gereken, sundukları vaatlerin gerçekçi olması, ürünü satmak için geliştirdiği küçük hilelere başvurmaktan kaçınmak olmalıdır. Özellikle yeşil aklama olarak bilinen ve markaların da sık sık başvurduğu bir pa- 
zarlama yöntemini markaların gözden geçirmesi, yeşil aklama yoluna gitmek yerine ürünlerini geliştirmeleri, zararlarını azaltmaları önerilmektedir. Çalışma bu yönüyle hem alanyazına hem de pazarlama yöneticilerine önemli katkılar sunabilmektedir. Bu nedenle de hem pazarlama disiplini hem de pazarlama uygulamaları için tüketici sinizmi konusundaki çalışmaların devamının gelmesi, tüketici sinizminin başka pazarlama uygulamalarıyla ilişkisinin test edilebileceği araştırmaların gerçekleştirilmesi gerekliliği bulunmaktadır. Örneğin bu kez ağızdan ağıza pazarlamanın tüketici sinizmi üzerindeki etkisi yerine, tersine tüketici sinizminin ağızdan ağıza pazarlama üzerindeki etkisine yönelik çalışmalar yapılarak alanyazın genişletilebilir ve buna yönelik olarak markalara öneriler sunulabilir. Böylece ülkemizdeki tüketici sinizmi çalışmalarının devam etmesi ile kavramın alanyazını gelişme kaydedecektir ve pazarlama uygulayıcıları da tüketici tutum ve davranışları konusunda daha fazla fikre sahip olarak, sonraki faaliyetlerini ona göre tasarlayabileceklerdir. 
EXTENDED ABSTRACT

\title{
The Concept of Consumer Cynicism and A Survey on The Effect of Word of Mouth Marketing Actions on Cynical Consumer Behavior
}

\author{
Bora Göktaş \\ Bayburt University
}

Brands make various marketing communication efforts for consumers to choose themselves. In these marketing communication activities, they make various promises in order to increase consumers' purchasing motivation and the consumer, who is convinced of these promises, fulfills the process of buying the brand. When the consumer who uses the brand is satisfied with this experience, he/she will continue his/her contact with the brand; but otherwise, consumer will interrupt communication. In order for this relationship to be permanent, what the brand says must match the customer's expectations. If that does not occur, the customer will cut off her/his relationship with the brand. The behavior of the customer who cuts the relationship may inevitably become cynical. When the consumer's behavior becomes cynical; as a frustrated person they will begin to have negative thoughts about brands. The customers can doubt the brands and feel that there are brands trying to deceive them and that they should not trust them. Thus, an enemy of the brand can emerge a consumer segment. Such consumers are called cynical consumers, and such a movement is called consumer cynicism. Of course, such a consumer shares her/his negative opinion about the brand with other consumers. At this point, the concept of "word of mouth marketing "emerges. In word of mouth marketing, actual customers talk about brands to potantial customers. Consumers who are satisfied with the use of one brand voluntarily transfer this to other consumers and make some kind of free marketing of the brand. However, when this is the case consumer cynism, a negative word of mouth marketing action will take place.

Negative word of mouth marketing is dangerous for brands and is a condition that must be coped. Because in a situation where the cynical 
consumer is also disappointed, suspected, deceived, betrayed, the brand is expected to be affected from negative word of mouth marketing. However, consumers can hardly be convinced when positive word of mouth marketing is conducted. With this paper, the existence and effect level of this way relationship between consumer cynicism and word of mouth marketing has been tried to be determined. First of all, it was tried to determine whether the participants had a cynical attitude and if they had a cynical attitude, it was tried to determine to what extent they were affected by word of mouth marketing actions. With the intention of finding an answer to the research subject, a questionnaire form was prepared and it was performed to 476 participants with convenience sampling method. The scale consists of two parts in itself. The first is the "consumer cynicism scale", a scale developed by Helm, Moulard and Richins in 2015, consisting of 8 items. The second one is "word of mouth marketing scale "and the studies of Gürcü (2018) and Akdoğan (2015) have been utilized. This scale consists of 34 items.

According to the findings, the participants have little cynical attitudes and behaviors, and some negative "word of mouth marketing" actions lead to cynic attitudes of the participants. This result is seen both in the mean of the dimensions and in the regression analysis. According to the results of both tests, participants may be judged to be slightly affected by "word of mouth marketing" actions in displaying cynical attitudes and behaviors. Thus, both of the alternative hypotheses (H1a and H1b) mentioned in the basic hypotheses of the research are acceptable. In this study; participants showed cynical consumer behavior; however, the level of these behaviors is not very high and it is concluded that negative word of mouth marketing activities increase the degree of these cynical attitudes and behaviors very little. In the study, it was observed that men and married people had more cynical attitude. However, women are more affected when faced with the pressure of cynicism. In the field of psychology, there are claims that women act with more pure emotions and men behave more cautiously. In addition, there are many studies showing that women exhibit more hedonic behaviors at the point of consumption and shopping than men. Based on these, it is possible to conclude that males exhibit more cynical consumer behavior. A married person has more responsibility 
than a single person. Therefore, it can be expected to behave more cautiously and exhibit cynical behavior. One of the factors that affect the individual's purchasing behavior in consumer behavior is the family. Therefore, it seems natural for married individuals to exhibit more cynical attitudes. Because a single individual is more comfortable, untidy and likely to act only by thinking of himself. But whether this is really the case should be supported by other studies. Therefore, there is a need for further studies on consumer cynicism for both the marketing discipline and marketing practices, and the need to conduct studies that test the relationship between consumer cynicism and other marketing practices. For example, instead of the effect of word of mouth marketing on consumer cynicism, literature can be expanded by studying the impact of consumer cynicism on word of mouth marketing and suggestions can be made to brands. Thus, with the continuation of consumer cynicism studies in Turkey, the literature of the concept will improve and marketing practitioners will have more ideas about consumer attitudes and behaviors and will be able to design their next activities accordingly.

\section{Kaynakça / References}

Akdoğan, Ç. (2015). Online tüketici yorumlarına ait genel tutum ile ağızdan ağıza pazarlama arasındaki ilişki. Yüksek Lisans Tezi, T.C. Trakya Üniversitesi Sosyal Bilimler Enstitüsü, Edirne.

Akgüç Çetinkaya, Ö. ve Ceng, E. (2018). Türkiye'deki black friday etkinliğinin tüketici sinizmi bağlamında bir değerlendirmesi, MANAS Sosyal Araştırmalar Dergisi, 7(4), 167180.

Alhouti, S. (2013). Csr and facets of value creation: The role of key moderators. Doktora Tezi, Department of Marketing in The Graduate School of The University of Alabama: Tuscaloosa.

Amezcua, B. ve Quintanilla, C. (2016). When ewom becomes cynical, International Journal of Consumer Studies, 40, 290-298.

Aroeana, L., Dousiosa, D. Ve Michaelidoub, N. (2019). Exploring interaction differences in microblogging word of mouth between entrepreneurial and conventional service providers. Computers in Human Behavior, 95, 324-336.

Arslan, E.T. (2012). Süleyman Demirel Üniversitesi İktisadi ve İdari Bilimler Fakültesi akademik personelinin genel ve örgütsel sinizm düzeyi. Doğuş Üniversitesi Dergisi, 13(1), 12-27. 
Ashley, C. ve Leonard, H.A. (2009). Betrayed by the buzz? Covert content and consumer-brand relationships. Journal of Public Policy \& Marketing, 28 (2), 212-220.

Atılgan, K.Ö., İnce, T. ve Yılmaz, S. (2017). Tüketicilerin satın alma niyetleri ve boykota yönelik tutumlarının tüketici sinizmi, fiyat şeffaflığı ve fiyat adaleti bağlamında incelenmesi. Ç.Ü. Sosyal Bilimler Enstitüsü Dergisi, 26(3), 34-44.

Balajia, M.S. Jhab, S., Senguptac, A.S. ve Krishnand, B.C. (2018). Are cynical customers satisfied differently? Role of negative inferred motive and customer participation in service recovery. Journal of Business Research, 86, 109-118.

Berdysheva, E. ve Romanova, R. (2017). Rethinking prices during an economic crisis: Calculation as a new mode of consumer behaviour in Russia, International Journal of Consumer Studies, 41, 397-403.

Bertilsson, J. (2015). The cynicism of consumer morality. Consumption Markets $\mathcal{E}$ Culture, 18(5), 447-467.

Bokaie, J. (2008). Cynicism halts functional growth. Haymarket Business Publications Ltd., London, United Kingdom.

Chang, A.H., Hsieh, S.H. ve Tseng, T.H. (2013) online brand community response to negative brand events: The role of group ewom. Internet Research, 23, 486-506.

Chowdhury, R.M.M.I ve Fernando, M. (2014). The relationships of empathy, moral Identity and cynicism with consumers' ethical beliefs: the mediating role of moral disengagement. Journal of Business Ethics, 124, 677-694.

Chylinski, M. ve Chu, A. (2008). Consumer cynicism: Antecedents and consequences, European Journal of Marketing, 44 (6), 796-837.

Demir, E., Saatçioğlu, Ö. ve İmrol, F. (2016). Uluslararası dergilerde yayımlanan eğitim araştırmalarının normallik varsayımları açısından incelenmesi, Current Research in Education, 2(3), 130-148.

Göktaş, B. (2017), Bütünleşik pazarlama iletişiminin marka imajına etkisi ve bir uygulama. Doktora Tezi, T.C. Gazi Üniversitesi Sosyal Bilimler Enstitüsü, Ankara.

Göktaş, B. ve Erdoğan Tarakçı, İ. (2018). Ağızdan ağıza pazarlamanın pazarlama araçları içerisindeki önemi ve satın alma davranışlarını şekillendirmesine yönelik bir uygulama. Üçüncü Sektör Sosyal Ekonomi,53 (3), 1019-1033. 


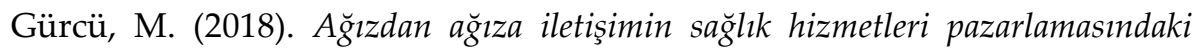
önemi ve tüketicilerin să̆lık hizmeti kullanım tercihi üzerindeki etkisi. Doktora Tezi, Gazi Üniversitesi Sosyal Bilimler Enstitüsü, Ankara.

Helm, A. E. (2004). Cynics and skeptics: Consumer dispositional trust. Advances in Consumer Research, 31, 345-351.

Helm, A. E. (2006). Cynical consumers: Dangerous enemies, Loyal friends. Doktora Tezi, University of Missouri, Columbia.

Helm, A.E., Julie Guidry Moulard, J.G. ve Richins, M. (2015). Consumer cynicism: Developing a scale to measure underlying attitudes influencing marketplace shaping and withdrawal behaviours. International Journal Of Consumer Studies, 39, 515-524.

Jahdi, K.S. (2006). A study of ethical green marketing. Doktora Tezi, Sheffield Hallam University, Sheffield.

Kanter, D, L, ve Mirvis, P, H, (1989). The cynical Americans; Living and working in an age of discontent and disillusion. San Francisco, CA: Jossey-Bass Inc.

Ketron, S. (2016). Consumer cynicism and perceived deception in vanity sizing: The moderating role of retailer (dis)honesty. Journal of Retailing and Consumer Services, 33, 33-42.

Kılıç, S. (2016). Cronbach'ın alfa güvenirlik katsayısı. Journal of Mood Disorders, $6(1), 47-48$.

Lia, Y, Wub, R., Lic, D. ve Fana, H. (2019). Can scarcity of products promote or restrain consumers' word-of-mouth in social networks? the moderating roles of products' social visibility and consumers' self-construal. Computers in Human Behavior, 95, 14-23.

Matzlera, K., Teichmannb, K., Stroblb, A. ve Partelc, M. (2019). The effect of price on word of mouth: First time versus heavy repeat visitors, Tourism Management, 70, 453-459.

Mehrad, D. ve Mohammadi, S. (2017). Word of mouth impact on the adoption of mobile banking in Iran. Telematics and Informatics, 34, 1351-1363.

Mikkonen, I., Moisander, J. ve Firat, A.F. (2011) Cynical 1dentity projects as consumer resistance: The scrooge as a social critic? Consumption Markets $\mathcal{E}$ Culture, 14, 99-116.

Naletelich, K. ve Ketron, S. (2017). Humanizing conservation: How anthropomorphism overcomes cynicism. AMA Summer Educators' Conference Proceedings, 28, 11-12. 
Odou, P. ve De Pechpeyrou, P. (2011). Consumer cynicism from resistance to anti-consumption in a disenchanted world? European Journal of Marketing, 45(11/12), 1799-1808.

Ogunfowora, B., Stackhouse, M. ve Oh, W.Y. (2015). Csr motıve attributions: the roles of executive leadership ethics and consumer cynicism. Academy of Management Annual Meeting Proceedings, 2015(1), 1306-1311.

Parka, S.J., Leea, Y.R. ve Borleb,S. (2018). The shape of word-of-mouth response function, Technological Forecasting \& Social Change, 127, 304-309.

Samuel, A., Taylor, D., White, G.R.T. ve Norris, M. (2018). Unpacking the authenticity gap in corporate social responsibility: Lessons learned from levi's 'go forth braddock' campaign, J Brand Manag, 25, 53-67.

Silverman, G. (2007). A ̈̆gıdan ă̆ıza pazarlama: Dünyanın en güçlü pazarlama yönteminin 28 Strrı (Çev. E. Orfanlı). İstanbul: Mediacat Kitapları.

Van Dolen, W.M., De Cremer, D. ve De Ruyter, K. (2012). Consumer cynicism toward collective buying: The interplay of others' outcomes, social value orientation and mood, Psychology and Marketing, 29(5), 306-321.

Yavuzyılmaz, O. (2008). A ̈̆gzdan ă̆ıza pazarlama:Kocaeli'de bulunan dershanelerdeki öğrenciler üzerine örnek bir araştırma. Yüksek Lisans Tezi, Kocaeli Üniversitesi Sosyal Bilimler Enstitüsü, Kocaeli.

Zhen, X. , Cai, G., Song, R. ve Jang, S. (2019). The effects of herding and word of mouth in a two-period advertising signaling model. European Journal of Operational Research, 275, 361-373.

\section{Kaynakça Bilgisi / Citation Information}

Göktaş, B. (2019). Tüketici sinizmi kavramı ve ağızdan ağıza pazarlama eylemlerinin sinik tüketici davranışlarına etkisi konusunda bir uygulama. OPUS-Uluslararası Toplum Araştırmaları Dergisi,13(19), 1650-1692. DOI: 10.26466/opus.581400 